NBER WORKING PAPER SERIES

\title{
UNILATERAL FACILITATION DOES NOT RAISE INTERNATIONAL LABOR MIGRATION FROM THE PHILIPPINES
}

\author{
Emily Beam \\ David McKenzie \\ Dean Yang \\ Working Paper 20759 \\ http://www.nber.org/papers/w20759 \\ NATIONAL BUREAU OF ECONOMIC RESEARCH \\ 1050 Massachusetts Avenue \\ Cambridge, MA 02138 \\ December 2014
}

We gratefully acknowledge funding support from the World Bank's Gender Action Plan and Research Support Budget.We thank Ditas Ravanilla and Sr. Adelia Oling for their crucial collaboration in this project, as well as PALFSI branch officers and staff for their support and assistance in implementation, Innovations for Poverty Action for overseeing the fieldwork, and in particular, Joma Gonzalez, Jaye Stapleton, Naomi Joseph, Veronica Gonzalez, Cree Jones, Amanda Chang, and the rest of the SWAP team. We obtained human subjects approval for this study from the University of Michigan, Health Sciences and Behavioral Sciences Institutional Review Board, project number HUM00034271, "The Determinants of Temporary Labor Migration in the Philippines." The views expressed herein are those of the authors and do not necessarily reflect the views of the National Bureau of Economic Research.

NBER working papers are circulated for discussion and comment purposes. They have not been peerreviewed or been subject to the review by the NBER Board of Directors that accompanies official NBER publications.

(C) 2014 by Emily Beam, David McKenzie, and Dean Yang. All rights reserved. Short sections of text, not to exceed two paragraphs, may be quoted without explicit permission provided that full credit, including $\odot$ notice, is given to the source. 
Unilateral Facilitation Does Not Raise International Labor Migration from the Philippines Emily Beam, David McKenzie, and Dean Yang

NBER Working Paper No. 20759

December 2014

JEL No. C93,F22,O15

\section{ABSTRACT}

Significant income gains from migrating from poorer to richer countries have motivated unilateral (source-country) policies facilitating labor emigration. However, their effectiveness is unknown. We conducted a large-scale randomized experiment in the Philippines testing the impact of unilaterally facilitating international labor migration. Our most intensive treatment doubled the rate of job offers but had no identifiable effect on international labor migration. Even the highest overseas job-search rate we induced (22\%) falls far short of the share initially expressing interest in migrating (34\%). We conclude that unilateral migration facilitation will at most induce a trickle, not a flood, of additional emigration.

\author{
Emily Beam \\ Department of Economics \\ National University of Singapore \\ 1 Arts Link AS2, \#04-38 \\ Singapore 117570 \\ ecsbea@nus.edu.sg \\ David McKenzie \\ The World Bank, MSN MC3-307 \\ 1818 H Street N.W. \\ Washington, DC 20433 \\ dmckenzie@worldbank.org
}

\author{
Dean Yang \\ University of Michigan \\ Department of Economics and \\ Gerald R. Ford School of Public Policy \\ 735 S. State Street, Room 3316 \\ Ann Arbor, MI 48109 \\ and NBER \\ deanyang@umich.edu
}




\section{Introduction}

Wage rates of workers using the same skills and doing the same jobs differ by as much as ten to one depending on the country in which they work (Ashenfelter, 2012). Moving from a developing to a developed country results in immediate large increases in income for the migrants, with gains that far exceed those of any other development policy intervention (Clemens, Montenegro, and Pritchett, 2009; Hanson, 2009; McKenzie, Gibson, and Stillman, 2010; Gibson and McKenzie, 2014). Why do so few people emigrate, and what policies can governments in developing countries pursue to make it easier for their citizens to escape poverty through international migration?

There is a growing literature in development economics that addresses the question of why households do not make objectively profitable investments such as using more fertilizer (Duflo et al., 2011), reinvesting profits in their businesses (Fafchamps et al., 2014), keeping enough small change (Beaman et al., 2014), and continuing in school (Jensen, 2010). These studies have shown that often a relatively small and inexpensive intervention, such as providing information or nudging behavior, can result in more households undertaking these investments. But the absolute scale of the returns to these investments is small - Duflo et al. (2011) estimate farmers stand to earn $\$ 10$ more per season from using fertilizer for example. ${ }^{1}$ In contrast Clemens et al. (2009) estimate that a marginal moderate-skill mover from a typical developing country to the United States would earn an additional \$10,000 per year, a gain 1,000 times as large. Yet to date there is very little literature to explain why more individuals do not take up these massive returns, or on what interventions can work in spurring them to do so.

Migration-source country governments have pursued two broad approaches to facilitating international migration for formal, legal work. Source countries can pursue unilateral facilitation policies on their own, without needing the cooperation of governments of migration-destination countries. Unilateral facilitation may involve provision of information, loan facilitation, and policies to ease the international job-search process. These policies act on the supply side of the migrant labor market and are similar in spirit to the types of interventions that have been shown to enable households to undertake smaller-scale profitable investments. Enhanced unilateral facilitation could have positive impacts on migration if immigration policies in destination

\footnotetext{
${ }^{1}$ Rosenzweig (2012) makes this point more systematically, showing that many such studies with large percentage gains amount to very small absolute gains.
} 
countries are sufficiently open, or if bilateral policies are already in place. Conversely, even though migration can have a high return, investing in obtaining information, in acquiring a passport, and in searching for overseas jobs may have low returns if border restrictions make the probability of being able to migrate abroad after undertaking this investment low.

Bilateral facilitation policies, on the other hand, involve cooperation with governments or employers in destination countries and include formalization of agreements to allow labor migration of specified numbers and types of workers. Such policies primarily attempt to influence the demand side of the migrant labor market, but they could also have supply-side components.

The Philippines has made perhaps the greatest progress among migration-source countries in implementing bilateral approaches, as evidenced by the existence of 49 bilateral migration agreements with 25 destination countries (Center for Migrant Advocacy, 2012) and an annual deployment of more than 2.0 million overseas Filipino workers (OFWs) worldwide (CFO, 2012). Consequently, overseas remittances top US\$25 billion annually, nearly 10\% of GDP (BSP 2012). However, the Philippines is not alone in promoting international migration; countries such as Bangladesh, Sri Lanka, and India are looking to the Philippine government's efforts as a model for promoting and regulating international migration (Ray et al., 2007). ${ }^{2}$

A wider range of countries have also attempted unilateral policies to ease the barriers preventing their citizens from migrating. For example, several Pacific Island governments such as Tuvalu have provided financing for seasonal workers wishing to migrate abroad (Bedford et al., 2010). A number of countries have made it easier for their citizens to obtain passports; Nepal, for example, decentralized the passport issuance process so that citizens no longer had to travel over mountain ranges to Kathmandu to obtain a passport (McKenzie, 2007). Other countries, such as Armenia, have attempted to provide potential migrants with more information about the disadvantages of illegal migration and about possibilities for legal jobs abroad (IOM, 2009). And Egypt created a jobs website better connect Egyptian jobseekers and employers abroad (Fandrich, 2009).

\footnotetext{
${ }^{2}$ While the Philippines ranks fourth globally in total remittances received annually, just behind Mexico, as a share of its own GDP, it ranks only $18^{\text {th }}$, behind countries including Nepal, Honduras, El Salvador, Serbia, and Bangladesh (Ratha, Mohapatra, and Silwal, 2010).
} 
Despite the spread of these policies, there is currently little rigorous empirical evidence on the effectiveness of either unilateral or bilateral migration facilitation in enabling individuals to benefit from the large income gains international migration offers. We implement a randomized experiment measuring the impact of unilateral migration facilitation. Our experiment is large in scale, implements unilateral facilitation at a range of intensities, and occurs in the Philippines, one of the world's most important sources of legal, temporary, international labor migration.

We implement our study in Sorsogon, a province that sends relatively few labor migrants overseas compared to other parts of the Philippines, but where one-third of households say they would like to migrate abroad. These features - existing and extensive bilateral labor migration arrangements, but relatively low migration relative to other parts of the country - make our experimental context one where unilateral migration policies could potentially have a substantial positive impact. While Sorsogon residents are underrepresented among OFWs, a good share is likely to be qualified for overseas work: more than two-thirds $(69 \%)$ of our sample had completed high school, and nearly half $(50 \%)$ had completed at least some post-secondary school. ${ }^{3} \mathrm{We}$ deliberately focus on a random sample of households, rather than selecting on initial interest in migration, in order to use our interventions to help assess the role of different explanations why most households don't migrate.

Our experiment tested the impact of unilateral facilitation policies modeled after potential low and medium-cost interventions to reduce informational, job-matching, and documentation barriers, which, as described above, have been used at least in part by a wide range of other countries. In addition to its active role in bilateral migration facilitation, the Philippines government has undertaken or has underway a number of unilateral efforts, such as warning migrants about illegal recruitment, providing information on cultural differences in different destinations abroad, and implementing new efforts to reduce the hassle of applying for a passport (Reyes, 2012).

The treatments we implement build on these policy efforts, but we refine them to isolate specific mechanisms that may prevent most people from migrating abroad. We target the

\footnotetext{
${ }^{3}$ The recruitment agencies we worked with were eager to attract workers from Sorsogon Province, particularly for jobs that require less-specialized work experience, for which they reported difficulty in filling vacancies. They were hesitant to recruit in rural areas because although they had no difficulty identifying qualified workers, in the past they found that applicants would initiate but could not complete the process.
} 
following mechanisms: 1) information (about job search, migrating abroad, financing migration, and passport processing); 2) frictions in job search (assistance in enrolling in an online jobfinding website set up by the project to lower search costs and facilitate matching between recruiters and workers); and 3) documentation barriers (assistance and a full subsidy for passport application). We randomized adults of prime migration age into various combinations of treatments facilitating international labor migration. Individuals were randomized into a control group that received no treatment or into treatment groups receiving one or more of the set of facilitation treatments.

Although we find that our package of interventions results in individuals taking more steps towards international migration, such as searching for work abroad, getting a job interview, and even getting a job offer, we find a precise zero impact of even our full package of assistance on the likelihood of international migration over a two-year period. Our point estimate is exactly zero, and the 95 -percent confidence interval is $[-1.4 \%,+1.4 \%]$. Thus reducing information, search, and documentation frictions through the methods tested here can explain at most why 1 in 100 don't migrate, and cannot explain why most people don't migrate abroad. This contrasts strongly with work on facilitating internal migration in which information and job postings were sufficient to get rural Thai migrants to go to nearby cities rather than Bangkok (Fuller et al. 1985), and a small subsidy equal to the cost of a bus ticket was sufficient to spur a large increase in internal seasonal migration in Bangladesh (Bryan et al. 2014). The difference here is, of course, that even with information, job-seeking assistance, and a passport, border restrictions are still in place and restrict migration. We find some evidence of remaining barriers on both the demand and supply sides for migrant labor that may explain this lack of migration.

\section{Setting}

The Philippines is a useful setting to study the impact of unilateral approaches. The Philippine government's extensive bilateral facilitation policies, along with strong international labor demand, have created many migration opportunities in the past few decades. The government directly encourages international emigration and regulates private labor recruiters. Numerous financial institutions provide financial services to help potential migrants pay recruitment fees (O'Neil, 2004). In the Philippines, even with this infrastructure in place, and despite the fact that the country's per capita GDP (around US\$2,000) is less than one tenth of 
that in developed countries, most Filipinos do not migrate, and five in six families do not receive remittances from workers abroad.

While the Philippines stands out as a promoter of international migration, it is far from alone in doing so. The promise of remittances and their potential to spur economic development has similarly motivated developed and developing country governments to encourage workers overseas either directly, through bilateral arrangements, or indirectly, by providing favorable tax treatment and incentives to encourage remittances (Puri and Ritzema, 1999; World Bank, 2006). The type of temporary migration common in the Philippines - legal migration of an individual as a temporary worker - is common worldwide, with almost all OECD countries having temporary worker programs; it is also the dominant form of labor migration into the Gulf countries, and to Singapore, Malaysia and Japan.

We conducted our experiment in Sorsogon, a rural province 10-12 hours by bus from the capital, Manila, where most recruitment activities take place. Reflecting its relative poverty and isolation, the Bicol region (where Sorsogon is located) has relatively low participation in international migration. The region accounts for 5.8\% of the Philippine population, but only $3.3 \%$ of the country's overseas worker deployments in 2011 (NSO, 2011).

We deliberately chose to focus on a random sample of households from this province, as detailed below. This enables us to examine what we consider to be the most important question, "why do most people not migrate?" An alternative approach would be to try to screen a population to obtain a group of individuals who are right at the margin of migrating, and see whether particular interventions are enough to push them over the threshold of migrating. Although we believe this would also be an interesting avenue to explore in future experiments, it would answer a much narrower question. But recent findings as to why individuals do not take high-return investments have stressed that it may be because individuals do not have the right information, or need a "nudge" to overcome behavioral biases (Jensen, 2010; Duflo et al., 2011). This suggests that focusing just on individuals who have already signaled their intent to migrate or who have taken steps towards doing so may miss out on individuals who could benefit substantially from information and other assistance.

\section{Methods}


Early in 2010, we randomly selected 42 barangays from 6 municipalities in Sorsogon Province in which to conduct the baseline survey. ${ }^{4}$ We collected a household roster from each barangay that included a list of households, and we used these to set barangay-specific target sample sizes proportional to population. We targeted approximately $5 \%$ of the total population from each barangay, or roughly $26 \%$ of households. We sorted households randomly and selected the first listed households to be our target. When a household could not be located or had no eligible members, we replaced it with the next household on the list.

From each household, interviewers screened the first member they met who had never worked abroad and was aged 20-45. Subsequent to the baseline survey, we learned from recruitment agencies that most individuals over age 40 would not be eligible for overseas work, so we restrict our baseline sample to the 4,153 individuals ages $20-40$ we interviewed. ${ }^{5}$ Houses selected were typically far enough apart from each other that concerns about information spillovers are second order; to the extent that there were spillovers, our treatment estimates are lower bounds on the differential impact of more information. The passport assistance was only offered to the respondents themselves, and so it is not subject to such spillovers. Appendix A.1 describes our project timeline and sampling procedure in greater detail.

Table 1 reports demographic characteristics of the sample from the baseline survey. $71 \%$ of respondents are female, reflecting the fact that women were more likely to be at home when our project staff visited the household, but also enabling us to target those most likely to benefit from a reduction in barriers to overseas migration. Unlike some other migrant-sending countries such as Mexico, India, and Bangladesh, where the majority of migrants are male, ${ }^{6}$ migration from the Philippines is female-dominated; between 1992-2009, 61\% of new hires for overseas work were women (McKenzie, Theoharides, and Yang, 2014). Respondents report relatively high educational attainment (69\% have completed high school and 36\% have completed at least some post-secondary schooling) but low levels of household income (averaging P7,400 pesos/month,

\footnotetext{
${ }^{4}$ A barangay is the smallest administrative division in the Philippines. The municipalities we selected each have between 25 and 65 barangays, and there are a total of roughly 42,000 barangays in the country.

${ }^{5}$ For the passport sample, we also required that individuals be between ages 20-40. Tables A12 and A13 demonstrate that our results are not affected by including the 855 respondents ages $41-45$ who participated in the baseline survey.

${ }^{6}$ Based on authors' calculations from 2000 data from the Global Bilateral Migration Database (World Bank Group 2011, Özden et al., 2011). Overall, the global stock of migrants is predominantly male. However, as of 2000, the estimated stock of migrants from the Philippines was $61.1 \%$ female, while the stock was $44.7 \%$ female from Mexico, 42.4\% female from Bangladesh, and 39.0\% female from India.
} 
or US\$165) suggesting they may have high returns to working overseas. ${ }^{7} 34 \%$ report that they are "interested" or "strongly interested" in working abroad.

We revisited respondents in 2012 to collect information on their overseas job-search knowledge, job-search behavior, and migration decisions. We ask whether and how respondents searched for work overseas between 2010-2012, and we classify respondents as having migrated if they obtained a job offer and migrated abroad during that period. ${ }^{8}$ We successfully surveyed $90.8 \%$ of respondents or another member of their household at endline, and we find no evidence of differential attrition across treatment assignment (Table A2). ${ }^{9}$ Our primary analytical sample consists of these $90.8 \%$ for whom we successfully fielded an endline survey of the respondent or a fellow household member. Among the $9.2 \%$ who could not be reached at endline in this manner, we fielded brief "log" surveys of neighbors on international labor migration by the respondent, and inclusion of these log surveys raises our total endline response rate (for the "migrate abroad" outcome) to $98.5 \%$. We show in section A.5 that our estimated impacts on migration are robust to use of the full (98.5\%) endline sample, which includes the log surveys.

\subsection{Theoretical Reasons Why More People Don't Migrate}

In the classic economic migration model, migration is an investment: individuals and households incur moving costs to generate returns via higher incomes (Sjaastad, 1962). Subsequent work acknowledges imperfect financial markets in developing countries can also create additional rationales for migrating such as to finance household investments (Stark and Bloom, 1985; Yang, 2006).

This framework suggests three main reasons why individuals do not migrate even when there are job opportunities and higher incomes to be earned abroad. First, individuals may have high disutility from moving and therefore may not wish to migrate internationally even though the monetary benefits outweigh the monetary costs. This is certainly not what many non-migrants say. For example, $51.1 \%$ of surveyed Filipinos aged 15 and older say they would like to work abroad if they had the opportunity (Gallup World Poll, 2010). Second, individuals may not be fully informed about the costs and benefits of migration. Perhaps because they do not get to

\footnotetext{
${ }^{7}$ This and all other conversions based on the average exchange rate from February-June 2010, 1 USD $=45.0497$ PHP (OANDA, 2012).

${ }^{8}$ See section A.1 for additional details on the endline survey.

${ }^{9}$ See section A.1 for additional details.
} 
observe the outcomes of the most successful individuals who leave (Wilson, 1987, Jensen 2010), potential migrants may underestimate the benefits of migration (McKenzie, Gibson, and Stillman, 2013). Third, individuals may wish to migrate but may be unable to do so because of various constraints such as credit market imperfections (McKenzie and Rapoport, 2007; Grogger and Hanson, 2011); documentation barriers such as difficulty in obtaining a passport (McKenzie, 2007); or frictions in job search that are exacerbated when searching internationally (Ortega, 2000; Lumpe and Weigert, 2009). We designed interventions to attempt to reduce these barriers.

However, we should note that the original Sjaastad (1962) model was written with internal migration in mind. In this model, any individual who pays the costs of migrating can do so if they choose. In contrast, international migration presents the further constraint of international borders, which limit migration opportunities. There are two ways we can modify the model to include the presence of these borders. The first is to view border restrictions as another element of the cost of migrating (e.g. paying for the qualifications to meet skilled migration requirements or paying recruitment fees to companies that can secure a job opening for you abroad). If these costs are large relative to the costs of information, job search frictions, and documentation, then interventions that change only these components of costs without relaxing border restrictions will have limited effect. Alternatively, instead of viewing the model as being about whether to invest in migration, it could be viewed as being about whether to invest in steps to migration, such as obtaining information about migration, searching for a job abroad, and getting a passport. The expected returns from investing in this technology will then depend on how easy it is to migrate once these other constraints are overcome - if border restrictions make the likelihood of migrating low, it may not be profitable to invest in efforts to migrate, even though migration itself is extremely profitable for those who get to migrate.

\subsection{Interventions}

\section{Information and website assistance}

During the baseline survey, we randomly assigned respondents to a control group or to one of four treatment groups designed to improve their information about and access to overseas work opportunities (Figure 1). These groups were application information [T1], financial information [T2], application and financial information [T1] + [T2], and website assistance [T4]. The application information consisted of information on typical overseas costs; the steps needed to 
apply for work abroad; an advertisement to enroll in Pilijobs.org, an overseas job-finding website designed as part of this project; ${ }^{10}$ and a list of ways to avoid illegal recruitment from the Philippine Overseas Employment Agency. Financial information consisted of typical placement fees for work abroad and a list of Manila-based financial companies that provide loans for placement fees.

To facilitate job-matching, we worked with several Manila-based overseas recruitment agencies and a Sorsogon microfinance NGO to develop a website, Pilijobs.org, to help respondents easily contact and apply with reputable recruitment agencies and to allow those agencies to directly post job opportunities that could be accessed by respondents. While several widely used job-finding websites for overseas work already exist in the Philippines, we developed a separate one to ensure that applicants would be put in contact only with highquality, properly licensed recruitment agencies and to track their enrollment and participation in the website. Five recruitment agencies used the site, both to post job listings and to review applicants, and we worked closely with them to obtain their feedback and to encourage their staff to use the website. Section A.2 includes additional details about Pilijobs.org

Website assistance [T4] was always assigned along with application and financial information $([\mathrm{T} 1]+[\mathrm{T} 2])$. It consisted of a paper form respondents could use to enroll in Pilijobs.org, and interviewers provided help if requested. Interviewers returned to pick up completed forms, or respondents returned them to a nearby office. Project staff encoded and uploaded forms to the website.

\section{Passport assistance}

Based on feedback from our partner recruitment agencies during the first stage of the project, we determined that another potential barrier to overseas migration was difficulty accessing a passport. Agencies reported that because of difficulty and delays many individuals encounter when applying for passports, they prioritized applicants who already had passports. In mid-2011, we randomly assigned a subset of our sample to one of two treatments targeted to help respondents get passports for overseas work, which were cross-randomized with our initial treatments to generate 15 total treatment and control cells (Figure 1).

10 The full text of these interventions is included in an online appendix, which can be found at https://sites.google.com/site/eabeam/webappendixa interventions.pdf. Note that pilijobs.org is no longer available, since it was taken down when our project ended. 
The first passport treatment, passport information [T3], provided respondents a flier on the importance of having a passport before applying for overseas work and the steps they could take to obtain a passport. The second passport treatment, passport assistance [T3]+[T5], involved the passport information treatment, plus a letter inviting respondents to participate in a program that fully subsidized the typical costs of applying for a passport (including transportation), along with project staff assistance with passport application.

Figure 1 shows the treatments, which range from the control group to "All information" (application, financial, and passport information [T1] $+[\mathrm{T} 2]+[\mathrm{T} 3]$ ) and "All information + website" ([T1] + [T2] + [T3] + [T4]). The most intensive treatment, "Full assistance," includes all information treatments, website assistance, and passport assistance $([\mathrm{T} 1]+[\mathrm{T} 2]+[\mathrm{T} 3]+[\mathrm{T} 4]$ $+[\mathrm{T5}])$.

\subsection{Randomization to treatment and control}

\section{Information and website assistance randomization}

Our baseline sample was randomly allocated to a control group or to one of four treatment groups: application information [T1], financial information [T2], application and financial information $([\mathrm{T} 1]+[\mathrm{T} 2])$, and website assistance $([\mathrm{T} 1]+[\mathrm{T} 2]+[\mathrm{T} 4])$. The sample was divided evenly between these five groups.

Each respondent's treatment assignment was blind to the interviewer until after he or she completed the baseline survey. Interviewers received sealed envelopes containing a thank-you letter, the information treatments (as assigned), and blank paper to balance the weight of the envelopes between treatment types so that the interviewer could not guess the treatment until the envelope was opened after the survey. Each envelope was labeled with the household identification number assigned to the respondent being interviewed, serving as the link between the respondent and treatment assignment.

Because of our partnership with the microfinance institution PALFSI, we anticipated that current clients might respond differently to treatment and have different characteristics from nonPALFSI clients. Envelopes were randomized by barangay and by microfinance client status in blocks of five. This procedure generated block randomization within 81 barangay-by-client- 
status stratification cells. Our regression estimates include indicator variables for each stratification cell as control variables.

\section{Passport randomization}

Respondents in the passport survey were randomly assigned with equal probability to a control group or to one of two treatment groups prior to implementation. We stratified members of the passport sample by baseline treatment group, whether they had enrolled in Pilijobs.org, barangay, and age. Specifically, we divided members of this sample into groups based on baseline treatment assignment and Pilijobs.org enrollment status, divided each group into barangays, sorted by age within each barangay-sample cell, and block-randomized by threes. These respondents were resurveyed and randomly assigned to a passport control group or to the passport information [T3] or passport assistance ([T3] + [T5]) interventions.

Our administrative records indicate that $9.6 \%$ of baseline respondents offered passport assistance successfully obtained a passport. Although the program provided a full subsidy of the cost of the passport and required documentation, as well as fully subsidized transport expenses, passport applicants still needed to devote substantial time and effort to obtain a passport. For example, each applicant traveled one to two hours to the regional office of the Department of Foreign Affairs in Legazpi City three separate times to apply for and receive their passport, and most applicants made additional trips to other local agencies to obtain required documentation for their passport application. The appendix (A.3 and Table A4) provides additional details on the passport assistance program and direct impacts of the interventions on passport acquisition.

\section{Balancing tests}

Columns 1 through 5 of Table A3 report mean values for a set of individual and household characteristics of respondents, separately for each of the four original treatment conditions plus the control group. In columns 6 through 8 of the table, we report the corresponding characteristics of respondents who were part of the passport sample, based on their assignment to the passport control, information, or assistance treatments. (Recall that these are overlapping treatments, but not all baseline respondents were part of the passport sample.) 
The various randomized treatments have similar observables to the respective control groups. While there are some cases where the mean value of a covariate in a treatment group is statistically significantly different from the mean value in the respective control group (indicated by one, two, or three stars for significance levels of $10 \%, 5 \%$, and $1 \%$, respectively), their frequency is commensurate with what we expect would occur by chance: out of 84 comparisons with the control group mean in the table, nine (10.7\%) are statistically significant at the $10 \%$ level or less. Our regression estimates will control for this set of baseline covariates, which should account for any biases due to these chance imbalances.

\subsection{Specifications}

We use the following specification to measure the impact of unilateral facilitation on jobsearch and migration:

$$
Y_{i}=\alpha+\sum_{j=1}^{14} \beta_{j} D_{i}^{j}+B^{\prime} \lambda+X^{\prime} \delta+\varepsilon_{i}
$$

where $Y_{i}$ is the outcome variable for respondent $i$, measured in the 2012 endline survey. $D_{i}^{j}$ is a binary indicator equal to one if respondent $i$ is assigned to combination $j$ of application information [T1], financial information [T2], passport information [T3], website assistance [T4], or passport assistance [T5].

Vector $B$ includes the barangay/client-status set of stratification cell fixed effects, along with an indicator for whether the respondent was randomly selected to be in the passport sample. The coefficient on this indicator would be non-zero if simply being interviewed in the passport sample affected our endline outcomes. (In practice, this coefficient is consistently close to zero and not statistically significant.) To increase the precision of our estimates, we also include a vector of pre-specified controls, $X$, for the following baseline characteristics: female (indicator); age (continuous); high school completion (indicator); some college or vocational training (indicator); college completion (indicator); interested in working abroad (indicator); willingness to take risks (0-10 scale); household income (in thousands of pesos); household savings (in

thousands of pesos); whether the household has ever taken out a loan (indicator); asset ownership (normalized index of durable asset holdings); whether the respondent has extended family overseas (indicator); and whether the respondent has immediate family overseas (indicator). 
Missing covariate values are coded as zeros, and we include a set of missing value indicator variables.

We have 14 mutually exclusive treatment categories in addition to an omitted control group, as outlined in Figure 1. In regressions for main text Tables 2 and 3, we estimate all coefficients, but to simplify presentation we report results for only the following five treatments:

1. Application, financial, and passport information [T1] + [T2] + [T3] (“All information")

2. Application information, financial information, passport information, and website assistance [T1] + [T2] + [T3] + [T4] (“All information + website")

3. Passport information and passport assistance ("Only Passport Assistance") [T3] $+[\mathrm{T} 5]$

4. Application information, financial information, passport information, and passport assistance [T1] + [T2] + [T3] + [T5] (“All information + passport”)

5. Application information, financial information, passport information, and website assistance, and passport assistance [T1] + [T2] + [T3] + [T4] + [T5] ("Full Assistance")

This specification enables us to report results for the full information treatment, and then for combinations of the website assistance and passport assistance with full information. We report the complete set of 14 treatment coefficients in Tables A10 and A11.

\section{Results}

We examine whether unilateral facilitation can increase international migration. In particular, we test four hypotheses:

H1: The massive gain in income possible from migration should result in high migration demand. Since the monetary gains from migration are likely to far exceed the monetary costs for most Filipinos (Clemens, Montenegro, and Pritchett, 2009), theory predicts most individuals will wish to migrate unless the disutility from moving is high. In fact only $33.9 \%$ of individuals say they interested or very interested in migration at baseline, and far fewer search for work overseas (5.1\% of the control group) between survey rounds.

H2: Incomplete information prevents individuals from realizing the gains from migration. If individuals underestimate the gains from migration (McKenzie, Gibson, and Stillman, 2013) or 
overstate the costs, then some individuals for whom it is optimal to migrate will decide not to do so. Knowledge is clearly incomplete - at baseline, one-quarter of individuals responded with "don't know" to the typical wages and costs of work overseas for six common destination countries, and the responses given by those who do give an answer also suggest considerable inaccuracies. For example, half of those who did respond estimated they would earn the same wage or less in high-wage Canada as they would in low-wage Saudi Arabia. At endline, only $14.3 \%$ of the control group can name a lender who can finance migration costs and only $19.9 \%$ know where to go to apply for a passport. However, the information treatments alone do not result in higher rates of job search or international migration.

Figure 2 highlights means of key outcomes across a representative subset of treatments. We see the rate of overseas job search (5.3\%) for the "All information" treatment is similar in magnitude, and not statistically different, from the 5.1\% rate in the control group, and that only $1.1 \%$ of the "All information" group migrates abroad over the two-year period. Table 2 provides regression estimates of the treatment effects for a broader range of job-search and migration outcomes over the two-year period and confirms this lack of impact. Table 3 restricts the regression analysis to the subset of individuals who indicated that they were interested in migrating at baseline. In this subsample, information alone induces statistically significant increases (at the 10\% level) in the likelihood of being invited to interview and attending an interview for work abroad, but there is no statistically significant impact of information alone on actual migration.

H3: Frictions in matching with recruiters limit international migration. Even if individuals have correct information and decide the gains from migration exceed the costs, they still need to match with a job abroad (Ortega, 2000; Lumpe and Weigert, 2009). The website treatment is intended to help individuals do this. Figure 2 shows that the combination of information and the website treatment ("All Information + Website") caused a substantial increase in the rate of search for work abroad, from $5.1 \%$ to $15.7 \%$. The regression-adjusted estimate of this treatment effect from Table 2 is nearly identical, indicating a 10.6 percentage-point increase (statistically significant at the $1 \%$ level). Despite inducing substantially higher search effort, the treatment causes no additional migration abroad: the coefficient estimate in Table 2 column 8 is very small in magnitude and is not significantly different from zero. For the subgroup expressing interest in migrating at baseline, Table 3 shows the website and information combination resulted in a 19.6 
percentage-point increase in job search and a 7.7 percentage-point increase in attending an interview (statistically significant at the $1 \%$ and 5\% levels, respectively), but much smaller and statistically insignificant increases in the job offer rate (4.1 percentage points) and in the migration rate (2.3 percentage points).

\section{H4: Documentation barriers prevent individuals from taking advantage of job openings} abroad. Lack of a passport may prevent recruiters from even considering individuals for job openings or prevent some of those who receive job offers from taking up these offers. Our most intensive "Full assistance" treatment, which combines information, website assistance, and assistance obtaining a passport, results in a $21.7 \%$ job-search rate (Figure 2), but it is still far short of the $33.9 \%$ reporting interest in migration at baseline. Table 2 shows that this 15.9 percentage-point increase in job search over the control group rate is statistically significant at the $1 \%$ level, and it mainly reflects increased online search (column 2, increase significant at the $1 \%$ level), in addition to some additional search via other methods, such as attending job fairs (column 4, increase significant at the 5\% level). The full assistance treatment also has positive impacts on job-interview invitations, interview attendance, and job offer receipt (columns 5-7, effects significant at the $10 \%, 5 \%$, and $10 \%$ levels respectively), and these effects are large relative to control group rates $(2.6 \%, 1.5 \%$, and $1.7 \%$, respectively). Despite these positive impacts on pre-migration outcomes, the treatment has no statistically significant impact on migration abroad: the point estimate is zero percentage points to the third decimal place (column 8). A 95-percent confidence interval for the impact is $[-1.4 \%,+1.4 \%]$.

Should we view these impacts as small or large? While this confidence interval includes impacts that are large in relative terms compared to the control group migration rate of $0.9 \%$, they are very small in absolute terms. Even at the upper end of our confidence interval, at most one out of one hundred individuals migrate as a result of the combined package of reduced barriers. In the words of Clemens (2011), the massive gains from international migration represent "trillion dollar bills on the sidewalk." At present only 1 in 100 individuals in our sample stops to pick up one of these bills, and at most, our full package of interventions succeeds in getting 1 more picked up - clearly then our interventions do not explain why the vast majority of people do not take up this opportunity. We are in agreement here with Rosenzweig (2012) who critiques the practice of viewing large percentage changes on small bases as large effects, when they represent very small absolute gains. 
Table 3 shows these effects are larger for the sub-group initially expressing interest in migration (for whom demand should not be the constraint), with a 26.6 percentage-point increase in job search, a 8.5 percentage-point increase in job-interview attendance, and a 7.3 percentagepoint increase in the likelihood of receiving a job offer abroad (all statistically significant at the $5 \%$ level or less). However, there is still only a statistically insignificant 1.7 percentage-point increase in migration abroad. That is, our full package of unilateral facilitation delivered to the subgroup interested in migrating still does not significantly increase migration. Since this is a subsample, the confidence interval is wider than for the full sample, but at $[-1.7 \%,+5.1 \%]$, it still covers only very modest absolute increases in migration rates.

The appendix (A.5, A.6, and Table A9) shows that these results are robust to a variety of specifications and to alternate measures of migration outcomes, including a follow-up effort in 2013 to check the migration status of those with job offers who had not yet migrated in 2012. In Tables A5 and A6, we examine the distribution of positions that individuals were offered as well as the distribution of countries in which these jobs were located. The most common jobs offered were for domestic helper (40.9\%), service worker $(8.6 \%)$, caregiver $(7.5 \%)$, and factory worker (7.5\%), and nearly half were located in the Middle East. Table A7 shows the migration outcomes by region, as of the 2012 survey: $31.2 \%$ of offers had led to migration.

In Table A8, we also examine the reasons some individuals with job offers did not migrate overall and by region. ${ }^{11}$ We do not find evidence that the jobs offered were reported to be undesirable overall, or that jobs in the Middle East are less likely to be found appealing. The most common reasons given were financial and health related: $24.1 \%$ say they could not afford migration costs, and $10.3 \%$ cite health issues or that they failed the medical exam. Additionally, at least $27.9 \%$ of unaccepted offers can be attributed to a lack of demand to migrate, either because of the conditions of the position ( $8.6 \%$ not interested in type of work, $6.9 \%$ salary too low), family obligations $(10.3 \%)$, or because the respondent was no longer interested in working $\operatorname{abroad}(1.7 \%)$.

\section{Conclusion}

\footnotetext{
${ }^{11}$ With a large sample of job offers, an alternative approach to exploring why not all people with job offers move would be to examine the heterogeneity of moves with respect to different baseline characteristics such as access to credit, skill level, health, and presence of young children. However, since we get so few moves overall, and the sample with job offers is small, unsurprisingly we find no significant heterogeneity in treatment impacts on migration.
} 
The large gain in income possible through international migration makes it a puzzle that so few individuals migrate abroad. We conduct a randomized impact evaluation of migration facilitation policies designed to overcome information, matching, and documentation constraints that may inhibit individuals from realizing these gains. These are policies that developing countries can implement unilaterally, without needing to reach bilateral agreements with migration destination countries.

Our results suggest that information constraints are not an important barrier to international labor migration. Despite individuals lacking complete knowledge about the incomes they could earn abroad, the costs of moving, or the process involved in migrating, we find that providing such information has no overall impact on either job search or international migration. ${ }^{12}$

In contrast, we do find that assisting individuals to match with recruiters through a jobs website and to overcome documentation barriers through passport assistance does increase in job-search effort and the likelihood of obtaining a job interview. These constraints therefore appear to inhibit individuals taking steps towards international migration, although even with our maximum intensity facilitation, the rate of overseas job search over a two-year period, $21.7 \%$, is still far short of the fraction of individuals expressing interest in overseas migration at the start of that period (33.9\%). We conclude that survey-based elicitations of migration interest are likely to exceed actual attempts at migration, even in response to intensive migration assistance.

However, these substantial impacts on job search lead to no large or statistically significant increases in actual migration. Only a minority of the additional respondents induced to search for jobs overseas in response to our most intensive facilitation treatment are invited to interview for overseas jobs or receive overseas job offers. (That said, the effects of the treatment on these outcomes are statistically significant and imply large proportional effects relative to low controlgroup rates of interviews and offers, but are still small in absolute magnitude) Substantial fractions of those induced to search for overseas jobs by our treatments appear to be screened out by those on the demand side of the migrant labor market - recruitment agencies and the ultimate overseas employers. This is consistent with recent work showing how binding minimum wages

\footnotetext{
12 One potential reason for this is that more accurate information may dissuade overly optimistic individuals from searching, balancing out an increase in search from individuals who undervalue the gains from migrating. Indeed we find (and show in Table A7) that providing only financial information or passport information without other facilitation has a small negative impact on job search, consistent with individuals understating the costs and complexity of moving.
} 
specific to occupation and destination limit the number of job openings abroad for Filipinos (McKenzie, Theoharides, and Yang, 2014). It is also consistent with the main barrier preventing international migration being a lack of opportunities to work abroad given visa restrictions. This could also in turn help explain the limited responsiveness to even our most intense intervention individuals may conclude rationally that the return to looking for a job abroad even with a passport and information is low-even if these jobs pay relatively high wages - because the likelihood of getting such jobs is so low.

Perhaps the most surprising result of our study is that, while our most intensive facilitation treatment delivers statistically significant increases in overseas job offers (that are large relative to control group rates), it has zero impact on actual overseas migration (over a two-year posttreatment window). This lack of impact serves to further underline the point that demand for international migration on the part of developing-country residents is likely to be overstated those induced by an intervention to receive actual job offers commonly reject those offers in the end. Our survey evidence on the reasons these jobs are declined fails to pinpoint a dominant reason behind such job-offer rejections. The most common reason, financial constraints (cited by nearly a quarter of job-offer decliners), does not distinguish whether individuals face actual financial constraints or whether they are indicative that the perceived benefits of migration do not exceed the perceived costs.

Together, these results indicate that unilateral facilitation policies related to information, job search, and documentation assistance are not sufficient to increase rates of international labor migration. We find evidence of multiple remaining barriers on both the supply side (relatively low interest on the part of potential migrants) and demand side (highly selective screening for interviews and job offers) for overseas work. Our findings indicate that policymakers aiming to expand access to migration, particularly for those in isolated areas, should not expect to achieve success if relying solely on unilateral migration facilitation, and brings to the fore the role of complementary bilateral facilitation policies. Investigating the effectiveness of such bilateral policies is an important avenue for future research.

\section{References}

Ashenfelter, Orley. 2012. “Comparing Real Wages.” NBER Working Paper Series, No. 18006. 
Bangko Sentral ng Pilipinas. 2012. “Overseas Filipinos' Cash Remittances by Country, by Source.” http://www.bsp.gov.ph/statistics/spei_pub/Table\%2034.pdf

Beaman, Lori, Jeremy MaGruder and Jonathan Robinson. 2014. "Minding Small Change Among Small Firms in Kenya," Journal of Development Economics, 108: 69-86.

Bedford, Charlotte, Bedford Richard, and Elsie Ho. 2010. "Engaging with New Zealand's Recognized Seasonal Employer Work Policy: The Case of Tuvalu," Asian and Pacific Migration Journal 19(3): 421-45.

Bryan, Gharad, Shyamal Chowdhury, and A. Musfiq Mobarak. 2014. "Underinvestment in a Profitable Technology: The Case of Seasonal Migration in Bangladesh.” Econometrica, 82 (5): 1671-1748.

Center for Migrant Advocacy, 2012. "Bilateral labor agreements and social security agreements," http://centerformigrantadvocacy.files.wordpress.com/2012/06/ bilateral-labor-agreements-and-social-security-agreements 1.pdf.

Clemens, Michael. 2011 "Economics and Emigration: Trillion-dollar bills on the sidewalk?" Journal of Economic Perspectives 25(3): 83-106.

Clemens, Michael, Claudio Montenegro, and Lant Pritchett. 2009. "The Place Premium: Wage Differences for Identical Workers across the US Border.” HKS Faculty Research Working Paper Series, No. RWP09-004.

Commission on Filipinos Overseas. 2012. “2008-2012 Overseas Employment Statistics.” http://www.poea.gov.ph/stats/2012_stats.pdf

Duflo, Esther, Michael Kremer and Jonathan Robinson. 2011. "Nudging Farmers to Use Fertilizer: Theory and Experimental Evidence from Kenya," American Economic Review 101(6): 2350-2390.

Fafchamps, Marcel, David McKenzie, Simon Quinn and Christopher Woodruff. 2014. "Microenterprise Growth and the Fly-paper Effect: Evidence from a Randomized Experiment in Ghana," Journal of Development Economics, 106: 211-226

Fandrich, Christine. 2009. "Facilitated International Egyptian Labor Migration and Development: The integrated migration information system as case study." The American University of Cairo www.aucegypt.edu/GAPP/cmrs/reports/Documents/IMISProjectEvaluation.pdf

Fuller, Theodore, Paul Lightfoot and Peerasit Kamnuansilpa 1985. "Toward Migration 
Management: A Field Experiment in Thailand," Economic Development and Cultural Change 33(3): 601-621.

Gallup. 2010. "Gallup World Poll."

Gibson, John, and David McKenzie. 2014. "The Development Impact of a Best Practice Seasonal Worker Policy." Review of Economics and Statistics 96(2): 229-43

Grogger, Jeffrey, and Gordon Hanson. 2011. "Income Maximization and the Selection and Sorting of Immigrants." Journal of Development Economics, 95(1): 42-57.

Hanson, Gordon. 2009. "The Economic Consequences of the International Migration of Labor." Annual Review of Economics, 1: 179-207.

International Organization for Migration (IOM) 2009. "IOM Armenia Projects: Facilitating Migration."

http://www.iom.int/jahia/webdav/shared/shared/mainsite/activities/countries/docs/armeni a/Armenia-facilitating-migration-2009.pdf

Jensen, Robert. 2010. "The (perceived) returns to education and the demand for schooling," Quarterly Journal of Economics 125(2): 515-48.

Lumpe, Christian, and Benjamin Weigert. 2009. "Immigration Policy, Equilibrium Unemployment, and Underinvestment in Human Capital.” Labour, 23(1): 97-130.

McKenzie, David. 2007. "Paper Walls Are Easier to Tear Down: Passport Costs and Legal Barriers to Emigration." World Development, 35(11): 2026-2039.

McKenzie, David, and Hillel Rapoport. 2007. "Network Effects and the Dynamics of Migration and Inequality: Theory and Evidence from Mexico." Journal of Development Economics, 84(1): 1-24.

McKenzie, David, Caroline Theoharides, and Dean Yang. 2014. "Distortions in the International Migrant Labor Market: Evidence from Filipino Migration and Wage Responses to Destination Country Economic Shocks." American Economic Journal: Applied Economics 6(2): 49-75.

McKenzie, David, John Gibson, and Steven Stillman. 2010. "How Important is Selection? Experimental vs. Non-Experimental Measures of the Income Gains from Migration." Journal of the European Economic Association, 8(4): 913-945.

McKenzie, David, John Gibson, and Steven Stillman. 2013. "A Land of Milk and Honey with Streets Paved with Gold: Do Emigrants Have Over-Optimistic Expectations about 
Incomes Abroad?" Journal of Development Economics, 102: 116-127.

National Statistics Office. 2011. "2011 Survey on Overseas Filipinos." www.census.gov.ph/sites/default/files/attachments/hsd/specialrelease/Tab1.pdf

OANDA. 2012. "Historical Exchange Rates." Accessed June 28, 2012.

O'Neil, Kevin. 2004. "Labor Export as Government Policy: The Case of the Philippines." Migration Information Source. Accessed 29 January, 2013.

Ortega, Javier. 2000. "Pareto-Improving Immigration in an Economy with Equilibrium Unemployment." Economic Journal, 110(460): 92-112.

Özden, Çağlar, Christopher R. Parsons, Maurice Schiff, and Terrie L. Walmsley. 2011. "Where on Earth is Everybody? The Evolution of Global Bilateral Migration 1960-2000." World Bank Economic Review, 25(1): 12-56.

Puri, Shivani, and Tineke Ritzema. 1999. "Migrant Worker Remittances, Micro-finance and the Informal Economy: Prospects and Issues." ILO Working Paper No. 21.

Ratha, Dilip, Sanket Mohapatra, and Ani Silwal. 2010. Migration and Remittances Factbook 2011. Washington, D.C.: World Bank.

Ray, Sougata, Anup Kumar Sinha, and Shekhar Chaudhuri. 2007. "Making Bangladesh a Leading Manpower Exporter: Chasing a Dream of US \$30 Billion Annual Migrant Remittances by 2015." Indian Institute of Management Calcutta.

Reyes, Fat. 2012. "14 mall-based passport offices to serve public by end of year - DFA." Philippine Daily Inquirer. 30 July.

Rosenzweig, Mark. 2012. "Thinking Small: Poor Economics: A Radical Rethinking of the Way to Fight Global Poverty: Review Essay.” Journal of Economic Literature, 50(1): 115-27

Sjaastad, Larry A. 1962. "The Costs and Returns of Human Migration." Journal of Political Economy, 70(5): 80-93.

Stark, Oded, and David E. Bloom. 1985. "The New Economics of Labor Migration." American Economic Review: Papers and Proceedings, 75(2): 173-178.

Wilson, William Julius. 1987. The Truly Disadvantaged. Chicago: University of Chicago Press.

World Bank. 2006. Global Economic Prospects 2006: Economic Implications of Remittances Washington D.C.: World Bank.

World Bank Group. 2011. "Global Bilateral Migration Database.” Last accessed 28 August 2013. 
Yang, Dean. 2006. "Why Do Migrants Return to Poor Countries? Evidence from Philippine Migrants' Responses to Exchange Rate Shocks." Review of Economics and Statistics, 88(4): 715-735. 
Table 1: Descriptive statistics.

\begin{tabular}{lccc}
\hline & Mean & S.D. & N \\
& $(1)$ & $(2)$ & $(3)$ \\
\hline Female & 0.71 & 0.46 & 4151 \\
Age (mean) & 31.65 & 6.06 & 4151 \\
High school graduate & 0.33 & 0.47 & 4151 \\
Some college or vocational & 0.23 & 0.42 & 4151 \\
College graduate & 0.13 & 0.34 & 4151 \\
Interested in working abroad & 0.34 & 0.47 & 4151 \\
& & & \\
Willing to take risks (1=low-10=high) & 5.39 & 3.53 & 4143 \\
Household income & 7.74 & 6.87 & 4084 \\
Household savings (uncond.) & 1.78 & 10.03 & 3927 \\
No household savings & 0.83 & 0.38 & 3927 \\
Anyone in HH ever take out loan & 0.53 & 0.50 & 4150 \\
Normalized asset index & 0.00 & 1.00 & 4151 \\
Any immediate fam. overseas & 0.13 & 0.34 & 4151 \\
Any extended fam., overseas & 0.54 & 0.50 & 4151 \\
& & & \\
Household size & 5.65 & 2.22 & 4151 \\
Employed & 0.41 & 0.49 & 4146 \\
Ever applied overseas & 0.15 & 0.35 & 4147 \\
Household receives remittances & 0.09 & 0.29 & 4149 \\
Ever uses Internet & 0.18 & 0.39 & 4149 \\
Observations & & & \\
\hline
\end{tabular}

Sample restricted to baseline respondents without missing data on education and past household member migration. Household income and savings reported in thousands of pesos. 


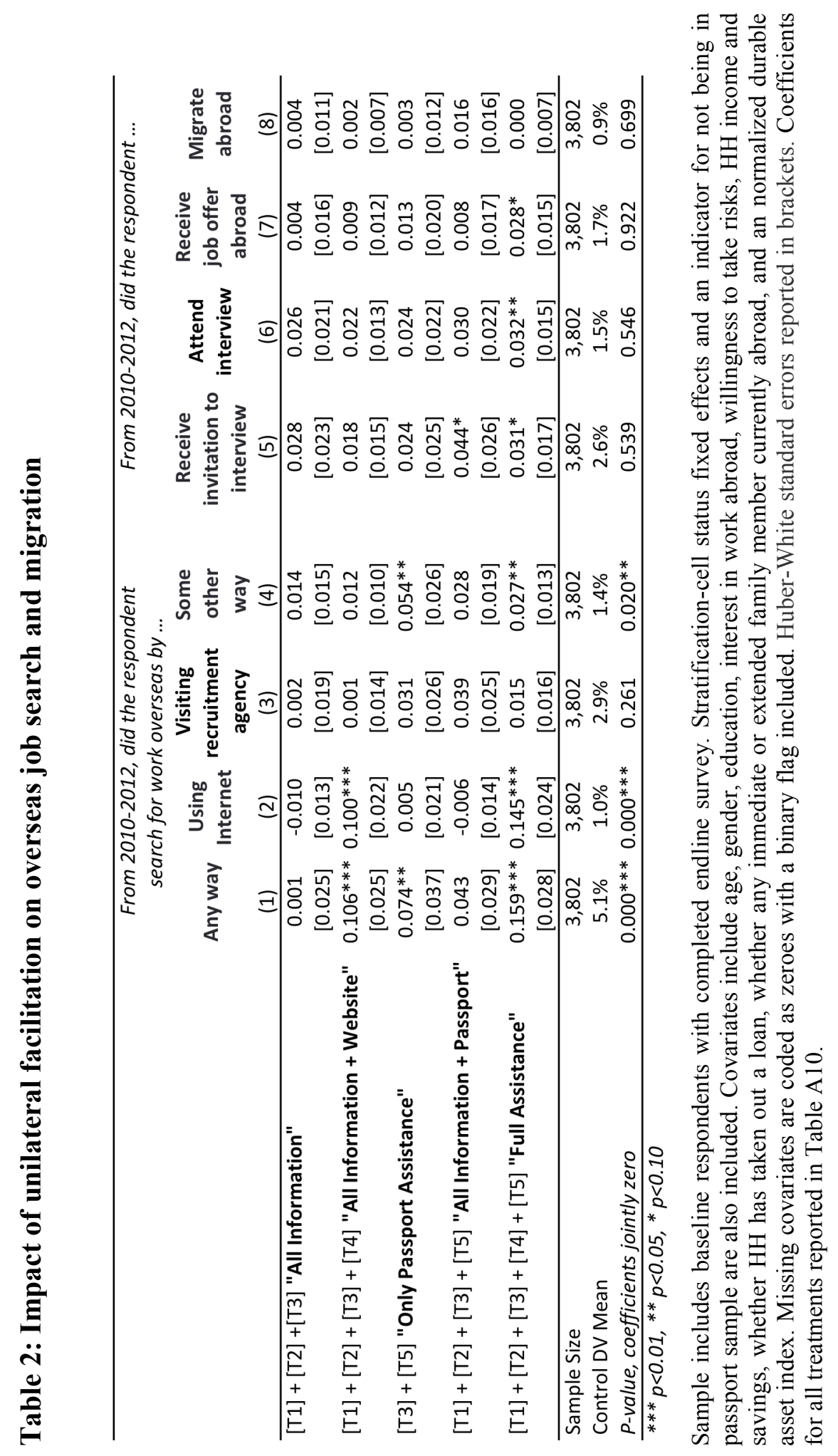




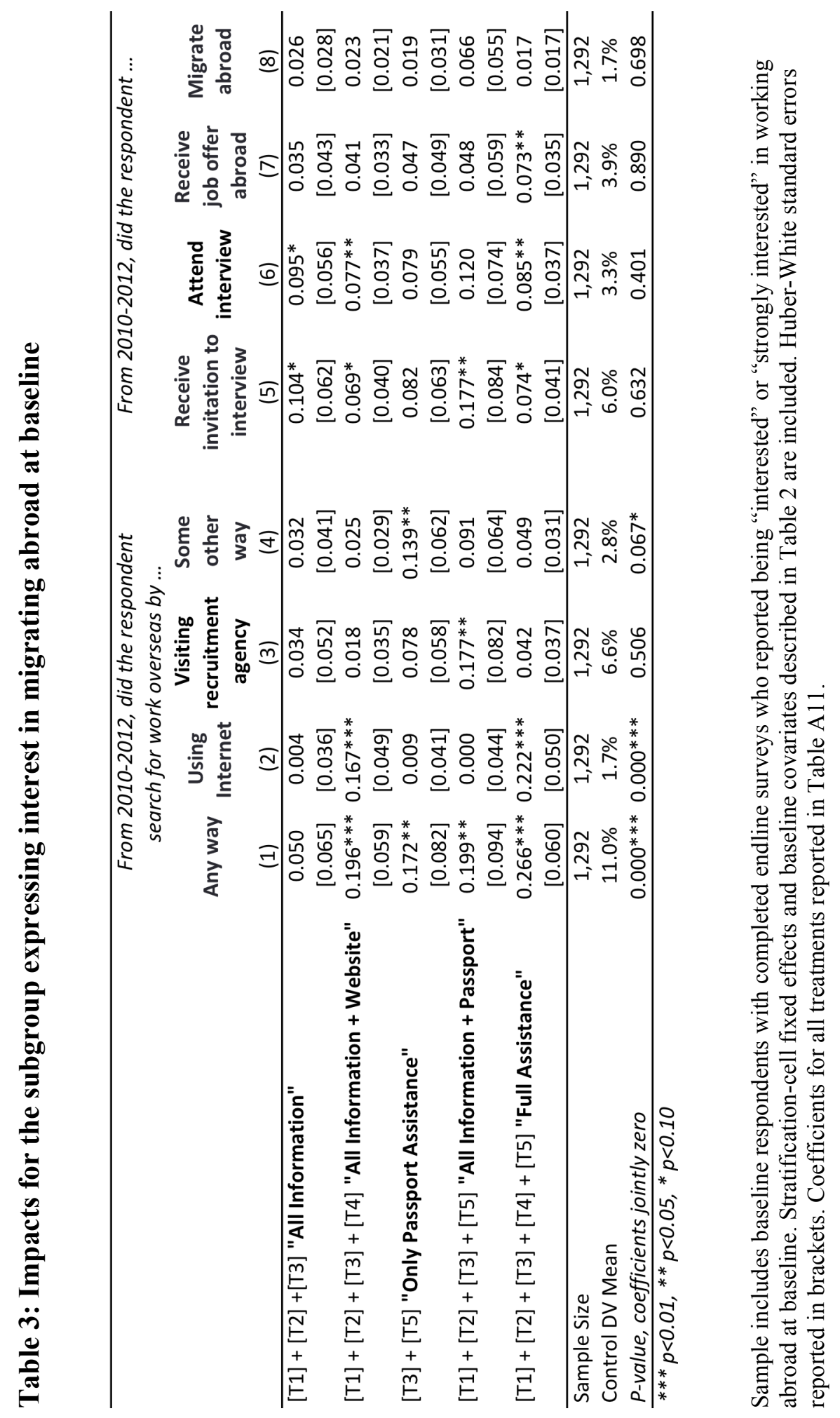


Figure 1: Treatment assignment.

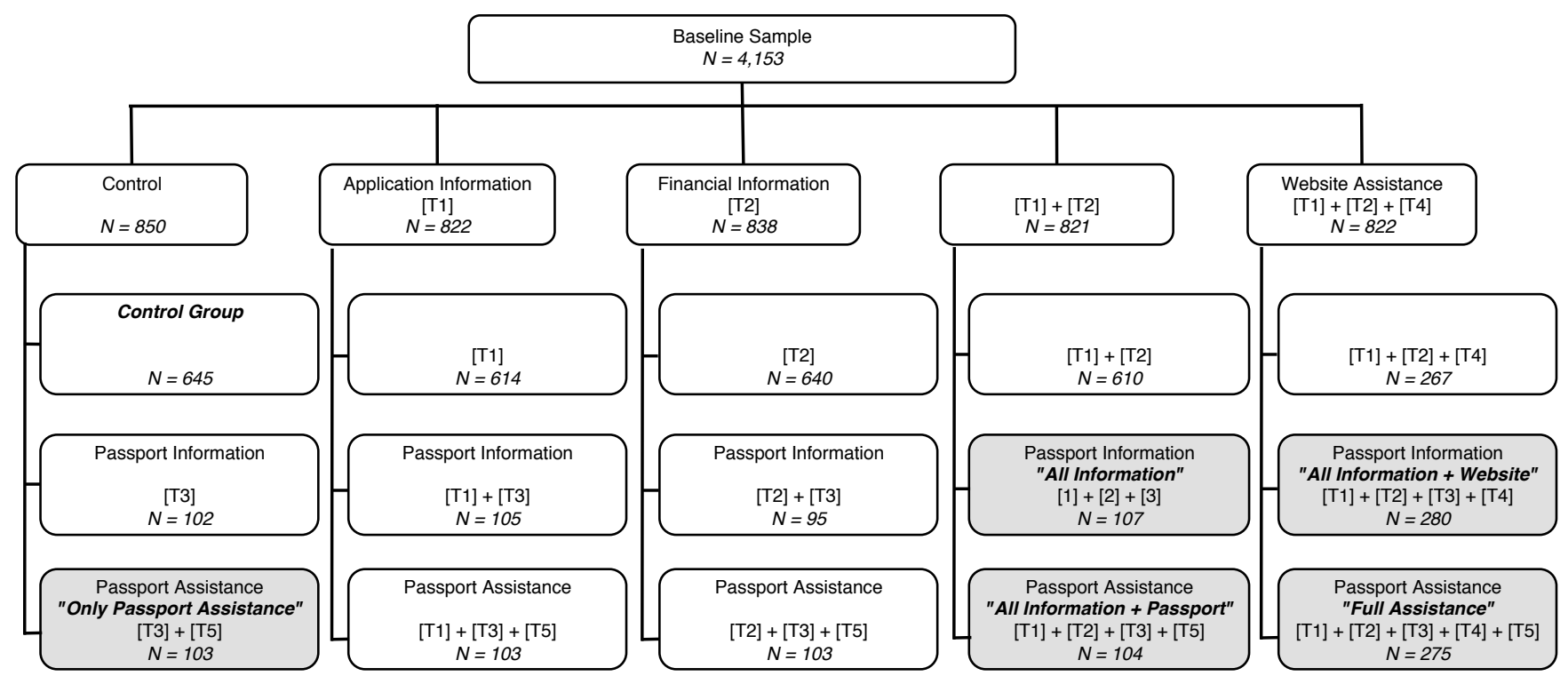

Sample includes all baseline respondents. Total observations per treatment assignment cell are reported in italics, which include those who attrit from the endline survey. Treatment coefficients for shaded boxes reported in Tables 2 and 3. The full set of treatment effects are reported in Tables A10 and A11. 
Figure 2: Reported interest in overseas migration, compared to search effort and realized migration across selected treatment conditions.

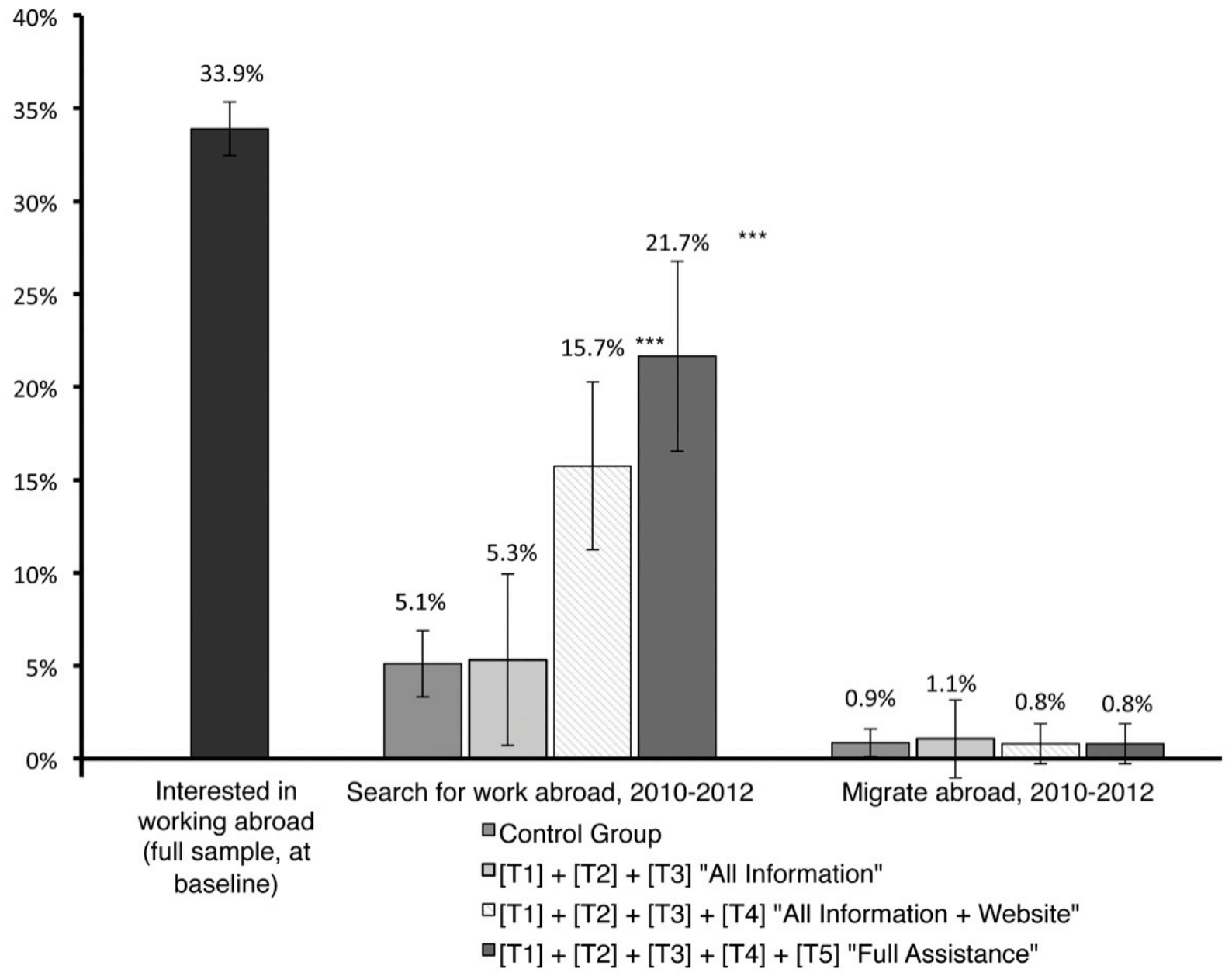

"Interested in working abroad" indicates respondent reported he/she was "interested" or "very interested" in migrating overseas at baseline (early 2010). Other variables reported in 2012 endline survey. Searching for work abroad includes asking family/friends, applying with a recruitment agency, applying online, or searching another way. Sample includes all baseline respondents with completed endline surveys. Error bars indicate $95 \%$ confidence intervals. See Figure 1 for treatment definitions. Stars indicate difference vs. control group is statistically significant at $10 \%(*), 5 \%(* *)$, and $1 \%(* * *)$ levels. 


\section{Online Appendix}

\section{A1.Data collection and sampling procedure}

Baseline survey (2010)

Table A1 presents the full timeline of our project. In early 2010, we selected six municipalities in Sorsogon for the baseline. These were selected to include both wealthier and poorer municipalities and both rural and urban areas. We then randomly selected 42 barangays: 11 from the capital of Sorsogon City, 7 from Casiguran, Castilla, Pilar, and Gubat, and 5 from Castilla and Irosin. Due to security and logistical considerations, three initially selected barangays were excluded and replaced with the next randomly selected barangay.

We obtained household rosters from each barangay captain, and we sorted households randomly then targeted the first listed households. Interviewers screened the first person they approached in the household. To be eligible for our study, the target respondent had to be between ages 20 and 45, and he or she must have not worked abroad in the past. Households that had current or past overseas Filipino workers (OFWs) were still eligible for the study. If the first household member was not eligible or did not want to participate in the survey, the interviewer asked if anyone else in the household might be eligible, and interviewed that person instead. We surveyed 5,008 individuals between March and August 2010, and 4,153 were ages 20-40.

\section{Passport follow-up (2011)}

In 2011, we launched the second stage of our project to provide some respondents with assistance obtaining a passport. We revisited a subset of our baseline sample. Specifically, of respondents ages 20-40, we included all who received the website treatment [T4], all Pilijobs.org enrollees in other treatment groups (32 respondents), 300 respondents randomly selected from each information treatment group ([T1], [T2], and [T1]+[T2]), and 300 respondents randomly selected from the control group.

At the time of the passport survey, we also interviewed and offered passport assistance to a supplemental sample of Sorsogon Province residents who enrolled in Pilijobs.org through other means that we describe in the next section (A.2), but who were not a part of our baseline sample. We do not include these respondents in our analysis.

\section{Endline survey (2012)}

We conducted an endline survey in mid-2012 to measure the impacts of our interventions. We visited all respondents from the baseline sample, making two attempts to reach each 
respondent. We interviewed another household member and administered a proxy survey when the respondent was not available, enabling us to obtain full data on respondent and household migration steps and job-search behavior when we could not directly reach the respondent. When no member of the household could be interviewed, we interviewed a neighbor using a "log" survey. The information collected in that survey was limited to the respondents' whereabouts, and whether he or she was currently working overseas. We show in A.5 that our finding of no impacts of the treatments on migration abroad are robust to expanding the sample to include these $\log$ surveys.

Using this three-pronged approach, we obtained measures of whether the respondent migrated abroad for work from full, proxy, or log surveys for 4,089 respondents, or $98.5 \%$ of our sample. Of those, $73 \%$ were surveys with the respondents themselves, $20 \%$ were proxy surveys, and $7 \%$ were $\log$ surveys. Excluding the log surveys, we have a $91 \%$ response rate for our full set of job search and migration outcome variables.

We provide full details on attrition rates in Table A2. In column 1, the dependent variable is an indicator for the endline either being completely missing or administered only via the log survey, in which case we are missing the pre-migration outcome measures we examine in columns 1-7 of Tables 2 and 3. We do not find evidence that either type of attrition is substantially related to treatment assignment. Coefficients on all treatments are small in magnitude, and although the coefficient on treatment [T2] + [T3] is individually significant, we cannot reject the null hypothesis that the treatment assignments are jointly unrelated to attrition.

In column 2, the dependent variable is an indicator for the respondent not being included in any of our endline surveys (respondent, proxy, or log surveys). Similar to column 2, we find some evidence of differential attrition for those assigned to treatments [T2] + [T3], significant at the 5\% level. However, the difference in response rates is small in magnitude (only 1.7 percentage points). We use the sample that does not include the log surveys for our main analysis, and only use this log survey data as a robustness check.

\section{A2.Pilijobs.org}

We developed Pilijobs.org in partnership with several Manila-based overseas recruitment agencies and our local microfinance partner (PALFSI). Pilijobs.org provided applicants with the opportunity to easily contact and apply for overseas jobs with reputable recruitment agencies, and allowed those agencies to directly post job opportunities that could be accessed by Sorsogon 
residents. We launched Pilijobs.org in early April 2010, within weeks of the start of the baseline survey period. Nearly all (91\%) of baseline respondents who enrolled in Pilijobs.org did so using paper forms, so their enrollment is unlikely to be affected by their brief delay between survey launch and the Pilijobs.org website launch.

In addition to the baseline applicants who enrolled online or through our paper forms, we recruited other applicants through door-to-door advertising in selected municipalities and barangays of Sorsogon Province that were not included in our baseline sample. This was done to ensure the website had enough of a user base to make it attractive to the recruiters. These applicants also received paper forms that staff encoded and uploaded to the website, and these advertising efforts all took place after completion of the baseline survey and interventions. We also advertised with bumper stickers and posters in municipalities that were not part of our baseline sample. To avoid spillovers, we did not use these general advertising methods in any of our baseline municipalities. Finally, we marketed Pilijobs.org broadly across the Philippines, using targeted Facebook advertising. All of these efforts resulted in an additional 5,500 enrollees, bringing the total enrollment in Pilijobs to roughly 7,100.

\section{A3.Impact on passport acquisition}

The payments we disbursed for the passport assistance treatment varied across applicants, ranging from P1250 (US\$28) for just transportation and the passport fee to P2350 (US\$52) for those with additional documentation requirements. Some applicants had costs that could not be subsidized by the program. For example, the project did not cover the expenses of amending a birth certificate or other documentation due to misspellings or erroneous information (with costs as much as P30,000). Approximately $11.6 \%$ of respondents initiated the passport process but were not able to complete it.

Because respondents may have obtained passports without directly interacting with our staff, these administrative records are not sufficient to test the impact of receiving passport information. Table A4 reports the impact our assigned treatments on whether respondents reported in the endline survey that they currently had a valid passport. All treatments that include passport assistance [T5] have positive effects on passport ownership that are statistically significant at the 5\% level or less. Effect sizes for these treatments range from 7.4 to 12.6 percentage points, which are large compared with the control group rate of $4.5 \%$. In addition, the most comprehensive treatment that does not include passport assistance [T5], "All information + 
Website" ([T1]+[T2]+[T3]+[T4]), also increases passport ownership by 5.1 percentage points (statistically significant at the $5 \%$ level).

\section{A4.Migration outcomes by region and reported reasons for not migrating}

Tables A5 through A8 present data from our endline survey on characteristics of overseas job offers that respondents reported. This includes the range of occupations (Table A5), destination countries (Table A6), and migration outcomes by region (Table A7). We also include reported reasons for not migrating, for those individuals who did receive an overseas job offer, in Table A8. We discuss these tables in the main text.

\section{A5.Impacts on migration, including endline data from log surveys}

All estimation results presented in the main text and here so far use data from respondent or proxy (other household member) surveys, which account for $91 \%$ of endline surveys. As noted above in column 1 of Table A2, there is no systematic pattern of differential inclusion in the respondent or proxy surveys related to treatment status.

That said, it is important to confirm that our (absence of) results for the impact of the treatments on migration overseas are robust to including responses from the "log" surveys of neighbors, which were administered when neither respondent nor proxy surveys could be successfully completed. Log surveys were very limited in content, asking only whether the respondent was currently living overseas and what they were doing abroad. Inclusion of the log survey responses on whether the respondent was working abroad raises our endline response rate to $98.5 \%$.

We report the impact of our treatments on whether respondents were currently working abroad, including log survey responses, in column 1 of Table A9. The results confirm our previously reported findings that use only the respondent and proxy surveys: there is no evidence of positive statistically significant impacts of any treatment on migration overseas. Indeed, we find that some information treatments may have actually reduced international migration. Those assigned to treatments [T2] + [T3] are 2.0 percentage points less likely to have migrated overseas, which is significantly different from zero at the $5 \%$ level. Some of these differences could have resulted from the differential attrition observed in Table A2, column 2, though it is possible that the information we provided respondents with new information on the difficulties involved in overseas labor migration, discouraging some respondents from seeking to migrate. However, we cannot reject the null hypothesis that all of the treatment effects are jointly zero. 


\section{A6.2013 supplementary survey of job-offer recipients}

At the time of the endline survey, $13.8 \%$ of those who had received overseas job offers but had not yet migrated reported that their migration was still pending (column 2, row 2, Table A8). One possibility we sought to examine was whether our endline survey took place too soon to capture migration effects. We conducted the endline survey from May through August 2012, which was between nine months and one year after we offered respondents passport assistance. Because the passport process was quite time-consuming, some respondents received their passports as late as three months before the endline survey, and they may not have yet had time to finish the migration process they initiated when we followed up with them.

To address this concern, in March and April 2013 we re-surveyed respondents who reported that anyone in their household was offered a job overseas between 2010 and 2012, including those who had offers they had not yet accepted. We asked them about the status of the offers they listed in the endline survey, as well as any offers that were received but not listed in the endline survey, either because they were not reported or because the offer was received after the endline survey took place.

From our set of baseline respondents, we attempted to contact 196 households, and we successfully completed 194 surveys (99\%). We completed 54\% with respondents and 46\% with a proxy household member. (Proxy survey rates are especially high for the 2013 offer survey because if the respondent was not available at the initial visit but another household member was willing to participate, we interviewed that member rather than schedule another visit.)

Using this 2013 survey of baseline respondents reporting job offers in the 2012 endline, we generate a modified indicator of overseas migration, measured nearly two years after initial passport treatment assignment. This variable modifies the previous "Migrate abroad" variable (in column 8 of Tables 2, 3, and A10 through A13) by additionally counting a respondent as having migrated if a job offer they reported in the 2012 endline survey is reported as having led to migration overseas in the 2013 survey. We did not modify the "Migrate abroad" variable if in the 2013 survey we learned that a respondent migrated but it was the result of a job offer not reported in the 2012 endline. This is because our objective here was simply to check whether our results would change if we allowed migration pending as of the 2012 endline to actually lead to migration. (To have done otherwise would have led to a false inflation of the treatment effect of 
"Full Assistance," because we only surveyed those with job offers in the 2013 survey, and because the "Full Assistance" treatment led to a higher rate of job offers.)

Column 2 of Table A9 reports the impacts of our treatments on this modified "Migrate abroad" variable. Our previous results are confirmed: there are no positive statistically significant impacts on migration, and impacts are similar in magnitude to the migration outcomes reported in column 8 of Table 2 .

\section{A.7. Additional specifications}

In Tables A10 and A11, we present the full set of results from the specifications used in Tables 2 and 3, respectively.

Tables A12 and A13 demonstrate that our previous results are robust to including individuals ages 41-45 in our sample. These individuals, as described earlier, were part of our baseline survey. However, we learned there are few overseas opportunities for new migrants over 40 . We restricted our passport sample to individuals aged 20-40 years old, and we define our baseline sample similarly, which better reflects the target population of unilateral migration facilitation efforts. 
Table A1: Project timeline

\begin{tabular}{|c|c|c|}
\hline Year & Month & Project Phase \\
\hline \multirow[t]{2}{*}{$\stackrel{0}{\stackrel{1}{0}}$} & $\begin{array}{l}\text { March } \\
\text { April } \\
\text { May } \\
\text { June } \\
\text { July } \\
\text { August }\end{array}$ & $\begin{array}{l}\text { Baseline survey and } \\
\text { info/web interventions }\end{array}$ \\
\hline & $\begin{array}{l}\text { September } \\
\text { October } \\
\text { November } \\
\text { December }\end{array}$ & \\
\hline \multirow{3}{*}{$\stackrel{+}{\mathbf{H}}$} & $\begin{array}{l}\text { January } \\
\text { February } \\
\text { March }\end{array}$ & \\
\hline & $\begin{array}{l}\text { April } \\
\text { May } \\
\text { June } \\
\text { July } \\
\text { August }\end{array}$ & $\begin{array}{c}\text { Passport survey and } \\
\text { passport interventions }\end{array}$ \\
\hline & $\begin{array}{l}\text { September } \\
\text { October } \\
\text { November } \\
\text { December }\end{array}$ & \\
\hline \multirow{3}{*}{$\stackrel{N}{\mathfrak{n}}$} & $\begin{array}{l}\text { January } \\
\text { February } \\
\text { March } \\
\text { April }\end{array}$ & \\
\hline & $\begin{array}{l}\text { May } \\
\text { June } \\
\text { July } \\
\text { August }\end{array}$ & Endline survey \\
\hline & $\begin{array}{l}\text { September } \\
\text { October } \\
\text { November } \\
\text { December }\end{array}$ & \\
\hline \multirow{3}{*}{$\stackrel{m}{\mathfrak{n}}$} & $\begin{array}{l}\text { January } \\
\text { February }\end{array}$ & \\
\hline & $\begin{array}{l}\text { March } \\
\text { April }\end{array}$ & Offer follow-up \\
\hline & May & \\
\hline
\end{tabular}




\begin{tabular}{|c|c|c|}
\hline & $\begin{array}{l}\text { Missing } \\
\text { respondent or } \\
\text { proxy survey } \\
(1) \\
\end{array}$ & $\begin{array}{c}\text { Missing } \\
\text { respondent, proxy, } \\
\text { or log survey } \\
\text { (2) }\end{array}$ \\
\hline \multirow[t]{2}{*}{ Application Information [T1] } & -0.009 & 0.006 \\
\hline & [0.016] & [0.007] \\
\hline \multirow[t]{2}{*}{ Financial Information [T2] } & -0.006 & 0.001 \\
\hline & [0.016] & {$[0.007]$} \\
\hline \multirow[t]{2}{*}{ Passport Information [T3] } & 0.018 & 0.004 \\
\hline & [0.034] & {$[0.016]$} \\
\hline \multirow[t]{2}{*}[\mathrm{T}1]{$+[\mathrm{T} 2]$} & -0.002 & -0.003 \\
\hline & [0.016] & {$[0.007]$} \\
\hline \multirow[t]{2}{*}[\mathrm{T}1]{$+[\mathrm{T} 3]$} & -0.016 & -0.009 \\
\hline & {$[0.030]$} & {$[0.012]$} \\
\hline \multirow[t]{2}{*}[\mathrm{T}2]{$+[\mathrm{T} 3]$} & $-0.051 * *$ & $-0.017^{* *}$ \\
\hline & {$[0.024]$} & {$[0.008]$} \\
\hline \multirow[t]{2}{*}[T1]{$+[T 2]+[T 3]$ "All Information" } & 0.039 & 0.002 \\
\hline & [0.035] & {$[0.015]$} \\
\hline \multirow[t]{2}{*}[\mathrm{T}1]{$+[\mathrm{T} 2]+$ Web. Assistance [T4] } & -0.002 & 0.006 \\
\hline & [0.023] & [0.012] \\
\hline \multirow[t]{2}{*}[\mathrm{T}1]{$+[\mathrm{T} 2]+[\mathrm{T} 3]+[\mathrm{T} 4]$ "All Information + Website" } & 0.010 & -0.006 \\
\hline & [0.023] & [0.010] \\
\hline \multirow[t]{2}{*}{ [T3] + [T5] "Only Passport Assistance" } & -0.002 & -0.008 \\
\hline & [0.031] & [0.013] \\
\hline \multirow[t]{2}{*}[\mathrm{T}1]{$+[\mathrm{T} 3]+[\mathrm{T} 5]$} & -0.004 & -0.010 \\
\hline & [0.032] & [0.013] \\
\hline \multirow[t]{2}{*}[\mathrm{T}2]{$+[\mathrm{T} 3]+[\mathrm{T} 5]$} & 0.002 & -0.004 \\
\hline & [0.031] & [0.013] \\
\hline \multirow[t]{2}{*}[T1]{$+[T 2]+[T 3]+[T 5]$ "All Information + Passport" } & -0.009 & 0.000 \\
\hline & [0.031] & {$[0.015]$} \\
\hline \multirow[t]{2}{*}[\mathrm{T}1]{$+[\mathrm{T} 2]+[\mathrm{T} 3]+[\mathrm{T} 4]+[\mathrm{T} 5]$ "Full Assistance" } & -0.004 & 0.009 \\
\hline & [0.023] & [0.012] \\
\hline Sample Size & 4,153 & 4,153 \\
\hline Control DV Mean & $9.2 \%$ & $1.4 \%$ \\
\hline$P$-value, coefficients jointly zero & 0.667 & $0.031 * *$ \\
\hline
\end{tabular}

Sample includes all baseline respondents. Stratification-cell fixed effects and baseline covariates described in Table 2 are included. Huber-White standard errors reported in brackets. 


\section{Table A3: Balancing tests}

\begin{tabular}{|c|c|c|c|c|c|c|c|c|}
\hline & \multicolumn{5}{|c|}{ Information/Website Assistance } & \multicolumn{3}{|c|}{ Passport Assistance } \\
\hline & $\begin{array}{c}\text { Control } \\
\text { (1) }\end{array}$ & $\begin{array}{c}\text { App. Info } \\
\text { (2) }\end{array}$ & $\begin{array}{l}\text { Fin. Info } \\
\text { (3) }\end{array}$ & $\begin{array}{l}\text { App. + } \\
\text { Fin. Info } \\
\text { (4) }\end{array}$ & $\begin{array}{c}\text { Website } \\
\text { Assist. } \\
\text { (5) }\end{array}$ & $\begin{array}{c}\text { Control } \\
\text { (6) }\end{array}$ & $\begin{array}{c}\text { Pass. } \\
\text { Info } \\
\text { (7) }\end{array}$ & $\begin{array}{c}\text { Pass. } \\
\text { Assist. } \\
\text { (8) }\end{array}$ \\
\hline Female & 0.70 & 0.73 & 0.70 & 0.71 & 0.68 & 0.70 & 0.67 & 0.71 \\
\hline Age (mean) & 31.86 & 31.56 & 31.64 & 31.87 & $31.33^{*}$ & 31.11 & $31.75^{*}$ & 31.59 \\
\hline High school graduate & 0.35 & $0.33^{*}$ & 0.30 & 0.34 & 0.32 & 0.35 & 0.34 & $0.30 * *$ \\
\hline Some college or vocational & 0.20 & $0.23 *$ & 0.24 & 0.23 & 0.23 & 0.23 & 0.22 & 0.26 \\
\hline College graduate & 0.14 & 0.12 & 0.13 & 0.13 & 0.15 & 0.15 & 0.14 & 0.12 \\
\hline Interested in working abroad & 0.33 & 0.31 & 0.36 & 0.32 & $0.38 * *$ & 0.37 & 0.37 & 0.37 \\
\hline Willing to take risks (1=low-10=high) & 5.23 & 5.23 & 5.47 & 5.27 & $5.75^{* * *}$ & 5.71 & 5.51 & 5.45 \\
\hline Household income & 7.69 & 7.38 & 7.89 & 7.36 & $8.41^{*}$ & 8.14 & 7.85 & 7.70 \\
\hline Household savings (uncond.) & 1.77 & 1.21 & 1.96 & 2.40 & 1.54 & 1.77 & 1.33 & 1.48 \\
\hline No household savings & 0.81 & $0.85^{* *}$ & 0.82 & 0.83 & 0.82 & 0.82 & 0.83 & 0.84 \\
\hline Anyone in $\mathrm{HH}$ ever take out loan & 0.54 & 0.53 & 0.51 & 0.58 & 0.50 & 0.54 & 0.53 & 0.50 \\
\hline Normalized asset index & -0.03 & -0.01 & 0.04 & -0.05 & $0.06^{*}$ & 0.06 & -0.02 & 0.00 \\
\hline Any immediate fam. overseas & 0.13 & 0.14 & 0.13 & 0.11 & 0.14 & 0.12 & 0.13 & 0.14 \\
\hline Any extended fam, overseas & 0.54 & 0.51 & 0.55 & 0.56 & 0.55 & 0.54 & 0.54 & 0.56 \\
\hline Observations & 849 & 821 & 838 & 821 & 822 & 681 & 689 & 687 \\
\hline
\end{tabular}

*** $p<0.01,{ }^{* *} p<0.05,{ }^{*} p<0.10$

Sample restricted to baseline respondents. Household income and savings reported in thousands of pesos. Columns 6-8 restricted to baseline participants who were randomly assigned to passport sample, as described in the appendix. Tests for statistically significant differences for each covariate include stratification cell-fixed effects and use HuberWhite standard errors. Stars indicate statistically significant differences between each information/website treatment groups (columns 2-5) and the information/website control group (column 1, and between each passport information and assistance treatment groups (columns 7-8) and the passport control group (column 6, those randomly selected to be in the passport group). 
Table A4: Impact of unilateral facilitation on passport acquisition

\begin{tabular}{|c|c|}
\hline & $\begin{array}{c}\text { Resp. has valid passport } \\
\text { (1) }\end{array}$ \\
\hline \multirow[t]{2}{*}{ Application Information [T1] } & -0.008 \\
\hline & {$[0.011]$} \\
\hline \multirow[t]{2}{*}{ Financial Information [T2] } & -0.002 \\
\hline & [0.012] \\
\hline \multirow[t]{2}{*}{ Passport Information [T3] } & -0.010 \\
\hline & {$[0.023]$} \\
\hline \multirow[t]{2}{*}[\mathrm{T}1]{$+[\mathrm{T} 2]$} & 0.008 \\
\hline & [0.013] \\
\hline \multirow[t]{2}{*}[\mathrm{T}1]{$+[\mathrm{T} 3]$} & 0.027 \\
\hline & {$[0.025]$} \\
\hline \multirow[t]{2}{*}[\mathrm{T}2]{$+[\mathrm{T} 3]$} & $0.048 *$ \\
\hline & {$[0.029]$} \\
\hline \multirow[t]{2}{*}[T1]{$+[T 2]+[T 3]$ "All Information" } & 0.017 \\
\hline & {$[0.025]$} \\
\hline \multirow[t]{2}{*}[\mathrm{T}1]{$+[\mathrm{T} 2]+$ Web. Assistance $[\mathrm{T} 4]$} & 0.010 \\
\hline & {$[0.020]$} \\
\hline \multirow[t]{2}{*}[\mathrm{T}1]{$+[\mathrm{T} 2]+[\mathrm{T} 3]+[\mathrm{T} 4]$ "All Information + Website" } & $0.049 * *$ \\
\hline & {$[0.020]$} \\
\hline \multirow[t]{2}{*}{ [T3] + [T5] "Only Passport Assistance" } & $0.126 * * *$ \\
\hline & {$[0.037]$} \\
\hline \multirow[t]{2}{*}[\mathrm{T}1]{$+[\mathrm{T} 3]+[\mathrm{T} 5]$} & $0.074 * *$ \\
\hline & {$[0.033]$} \\
\hline \multirow[t]{2}{*}[\mathrm{T}2]{$+[\mathrm{T} 3]+[\mathrm{T} 5]$} & $0.126 * * *$ \\
\hline & {$[0.037]$} \\
\hline \multirow[t]{2}{*}[T1]{$+[T 2]+[T 3]+[T 5]$ "All Information + Passport" } & $0.125^{* * *}$ \\
\hline & {$[0.037]$} \\
\hline \multirow[t]{2}{*}[T1]{$+[T 2]+[T 3]+[T 4]+[T 5]$ "Full Assistance" } & $0.121^{* * *}$ \\
\hline & {$[0.024]$} \\
\hline Sample Size & 3,763 \\
\hline Control DV Mean & $4.5 \%$ \\
\hline$P$-value, coefficients jointly zero & $0.000 * * *$ \\
\hline
\end{tabular}

Sample includes baseline respondents with completed endline survey. Stratification-cell fixed effects and baseline covariates described in Table 2 are included. Huber-White standard errors reported in brackets. Passport status is reported for full and proxy surveys with non-missing responses. 
Table A5: Jobs offered abroad, by position type

\begin{tabular}{lcc}
\hline \multicolumn{1}{c}{ Position } & $\mathbf{N}$ & Share \\
& $(1)$ & $(2)$ \\
\hline Domestic Helper (incl. babysitter/housekeeper) & 38 & $40.9 \%$ \\
Service worker (food, sales, etc.) & 8 & $8.6 \%$ \\
Caregiver & 7 & $7.5 \%$ \\
Factory worker & 7 & $7.5 \%$ \\
Nurse/nursing assistant & 4 & $4.3 \%$ \\
Cook & 3 & $3.2 \%$ \\
Skilled trade (mason, welder, carpenter, etc.) & 3 & $3.2 \%$ \\
Mechanic & 2 & $2.2 \%$ \\
Office worker & 2 & $2.2 \%$ \\
Technician & 2 & $2.2 \%$ \\
Agriculturist & 1 & $1.1 \%$ \\
Camera man & 1 & $1.1 \%$ \\
Encoder & 1 & $1.1 \%$ \\
General labor/construction & 1 & $1.1 \%$ \\
Seaman & 1 & $1.1 \%$ \\
Security Guard & 1 & $1.1 \%$ \\
Site Engineer & 1 & $1.1 \%$ \\
Utility & 1 & $1.1 \%$ \\
Missing/Don't know & 9 & $9.7 \%$ \\
Total & & 93 \\
\hline
\end{tabular}

Counts include all reported job offers respondents received from 2010-2012. 
Table A6: Jobs offered abroad, by location of position

\begin{tabular}{lcc}
\hline & Postion & Share \\
& $(1)$ & $(2)$ \\
\hline United Arab Emirates & 15 & $16.1 \%$ \\
Hong Kong & 12 & $12.9 \%$ \\
Saudi Arabia & 11 & $11.8 \%$ \\
Qatar & 7 & $7.5 \%$ \\
Kuwait & 6 & $6.5 \%$ \\
Taiwan & 5 & $5.4 \%$ \\
Malaysia & 4 & $4.3 \%$ \\
Canada & 3 & $3.2 \%$ \\
Singapore & $3 \%$ \\
Bahrain & 3 & $3.2 \%$ \\
Korea & 2 & $2.2 \%$ \\
Lebanon & 2 & $2.2 \%$ \\
United Kingdom & 2 & $2.2 \%$ \\
USA & 2 & $2.2 \%$ \\
Australia & 2 & $2.2 \%$ \\
Cyprus & 1 & $1.1 \%$ \\
Iran & 1 & $1.1 \%$ \\
Italy & 1 & $1.1 \%$ \\
Libya & 1 & $1.1 \%$ \\
Missing/Don't know & 1 & $1.1 \%$ \\
Total & 12 & $12.9 \%$ \\
\hline
\end{tabular}

Counts include all reported job offers respondents received from 2010-2012. 
Table A7: Migration outcomes of all job offers as of 2012, by region

\begin{tabular}{|c|c|c|c|c|c|c|c|c|c|c|}
\hline \multirow[t]{2}{*}{ Reason for not migrating } & \multicolumn{2}{|c|}{ TOTAL } & \multicolumn{2}{|c|}{ Middle East } & \multicolumn{2}{|c|}{ Asia } & \multicolumn{2}{|c|}{$\begin{array}{c}\text { N. America/ } \\
\text { Europe/Australia }\end{array}$} & \multicolumn{2}{|c|}{$\begin{array}{c}\text { Don't } \\
\text { know/Missing }\end{array}$} \\
\hline & $\begin{array}{c}\mathbf{N} \\
(1)\end{array}$ & $\begin{array}{l}\text { Share } \\
(2)\end{array}$ & $\begin{array}{c}\mathbf{N} \\
(3)\end{array}$ & $\begin{array}{l}\text { Share } \\
(4)\end{array}$ & $\begin{array}{l}\mathbf{N} \\
(5)\end{array}$ & $\begin{array}{l}\text { Share } \\
(6)\end{array}$ & $\begin{array}{c}\mathbf{N} \\
(7)\end{array}$ & $\begin{array}{l}\text { Share } \\
\text { (8) }\end{array}$ & $\begin{array}{c}\mathbf{N} \\
(9)\end{array}$ & $\begin{array}{c}\text { Share } \\
(10)\end{array}$ \\
\hline Migrate & 29 & $31.2 \%$ & 20 & $44.4 \%$ & 5 & $20.0 \%$ & 4 & $40.0 \%$ & 0 & $0.0 \%$ \\
\hline Accept offer, migration pending & 6 & $6.5 \%$ & 3 & $6.7 \%$ & 1 & $4.0 \%$ & 2 & $20.0 \%$ & 0 & $0.0 \%$ \\
\hline Accept offer, did not migrate & 39 & $41.9 \%$ & 18 & $40.0 \%$ & 13 & $52.0 \%$ & 4 & $40.0 \%$ & 4 & $30.8 \%$ \\
\hline Did not accept offer & 19 & $20.4 \%$ & 4 & $8.9 \%$ & 6 & $24.0 \%$ & 0 & $0.0 \%$ & 9 & $69.2 \%$ \\
\hline Total & \multicolumn{2}{|c|}{93} & \multicolumn{2}{|c|}{45} & \multicolumn{2}{|c|}{25} & \multicolumn{2}{|c|}{10} & \multicolumn{2}{|c|}{13} \\
\hline
\end{tabular}

Counts include all reported job offers respondents received from 2010-2012.

Table A8: Reported reasons for not migrating, conditional on receiving an overseas job offer

\begin{tabular}{|c|c|c|c|c|c|c|c|c|c|c|}
\hline \multirow[t]{2}{*}{ Reason for not migrating } & \multicolumn{2}{|c|}{ TOTAL } & \multicolumn{2}{|c|}{ Middle East } & \multicolumn{2}{|c|}{ Asia } & \multicolumn{2}{|c|}{$\begin{array}{c}\text { N. America/ } \\
\text { Europe/Australia }\end{array}$} & \multicolumn{2}{|c|}{$\begin{array}{c}\text { Don't } \\
\text { know/Missing }\end{array}$} \\
\hline & $\begin{array}{c}\mathbf{N} \\
(1)\end{array}$ & $\begin{array}{c}\text { Share } \\
(2)\end{array}$ & $\underset{(3)}{\mathbf{N}}$ & $\begin{array}{c}\text { Share } \\
(4)\end{array}$ & $\begin{array}{c}\mathbf{N} \\
(5)\end{array}$ & $\begin{array}{c}\text { Share } \\
(6)\end{array}$ & $\begin{array}{c}\mathbf{N} \\
(7)\end{array}$ & $\begin{array}{l}\text { Share } \\
\text { (8) }\end{array}$ & $\begin{array}{c}\mathbf{N} \\
(9)\end{array}$ & $\begin{array}{c}\text { Share } \\
(10)\end{array}$ \\
\hline Could not afford expenses & 14 & $24.1 \%$ & 4 & $18.2 \%$ & 8 & $40.0 \%$ & 1 & $20.0 \%$ & 1 & $9.1 \%$ \\
\hline Migration still pending & 8 & $13.8 \%$ & 3 & $13.6 \%$ & 2 & $10.0 \%$ & 2 & $40.0 \%$ & 1 & $9.1 \%$ \\
\hline Health problems/fail medical exam & 6 & $10.3 \%$ & 3 & $13.6 \%$ & 2 & $10.0 \%$ & 1 & $20.0 \%$ & 0 & $0.0 \%$ \\
\hline Family obligations & 6 & $10.3 \%$ & 3 & $13.6 \%$ & 2 & $10.0 \%$ & 0 & $0.0 \%$ & 1 & $9.1 \%$ \\
\hline Not interested in type of work & 5 & $8.6 \%$ & 2 & $9.1 \%$ & 2 & $10.0 \%$ & 0 & $0.0 \%$ & 1 & $9.1 \%$ \\
\hline Problem with respondent qualifications & 5 & $8.6 \%$ & 3 & $13.6 \%$ & 0 & $0.0 \%$ & 0 & $0.0 \%$ & 2 & $18.2 \%$ \\
\hline Salary too low & 4 & $6.9 \%$ & 1 & $4.5 \%$ & 1 & $5.0 \%$ & 0 & $0.0 \%$ & 2 & $18.2 \%$ \\
\hline Training not completed & 3 & $5.2 \%$ & 1 & $4.5 \%$ & 1 & $5.0 \%$ & 1 & $20.0 \%$ & 0 & $0.0 \%$ \\
\hline Problem with documentation/passport & 3 & $5.2 \%$ & 1 & $4.5 \%$ & 0 & $0.0 \%$ & 0 & $0.0 \%$ & 2 & $18.2 \%$ \\
\hline Other/missing & 2 & $3.4 \%$ & 0 & $0.0 \%$ & 1 & $5.0 \%$ & 0 & $0.0 \%$ & 1 & $9.1 \%$ \\
\hline Not interested in working abroad & 1 & $1.7 \%$ & 0 & $0.0 \%$ & 1 & $5.0 \%$ & 0 & $0.0 \%$ & 0 & $0.0 \%$ \\
\hline Offer changed/no longer available & 1 & $1.7 \%$ & 1 & $4.5 \%$ & 0 & $0.0 \%$ & 0 & $0.0 \%$ & 0 & $0.0 \%$ \\
\hline Total & \multicolumn{2}{|c|}{58} & \multicolumn{2}{|c|}{22} & \multicolumn{2}{|c|}{20} & \multicolumn{2}{|c|}{5} & \multicolumn{2}{|c|}{11} \\
\hline
\end{tabular}

Counts include all reported job offers respondents received from 2010-2012 that did not lead to migration, for which respondents reported why they did not migrate, as of the endline survey. 
Table A9: Impact of unilateral facilitation on alternate migration measures

\begin{tabular}{|c|c|c|}
\hline & $\begin{array}{l}\text { All surveys } \\
\text { In 2012, respondent } \\
\text { working abroad } \\
\text { (1) }\end{array}$ & $\begin{array}{l}\text { Respondent }+ \text { proxy } \\
\text { By 2013, respondent } \\
\text { migrated (confirmed } \\
\text { offers) } \\
\text { (2) }\end{array}$ \\
\hline \multirow[t]{2}{*}{ Application Information [T1] } & -0.007 & -0.003 \\
\hline & {$[0.005]$} & [0.005] \\
\hline \multirow[t]{2}{*}{ Financial Information [T2] } & -0.005 & -0.003 \\
\hline & {$[0.006]$} & [0.006] \\
\hline \multirow[t]{2}{*}{ Passport Information [T3] } & -0.005 & 0.004 \\
\hline & {$[0.012]$} & [0.012] \\
\hline \multirow[t]{2}{*}[\mathrm{T}1]{$+[\mathrm{T} 2]$} & -0.009 & -0.006 \\
\hline & {$[0.007]$} & [0.006] \\
\hline \multirow[t]{2}{*}[\mathrm{T}1]{$+[\mathrm{T} 3]$} & $-0.017 * *$ & -0.007 \\
\hline & {$[0.008]$} & {$[0.005]$} \\
\hline \multirow[t]{2}{*}[\mathrm{T}2]{$+[\mathrm{T} 3]$} & $-0.020 * *$ & $-0.010 *$ \\
\hline & {$[0.009]$} & {$[0.006]$} \\
\hline \multirow[t]{2}{*}{ [T1] + [T2] +[T3] "All Information" } & -0.010 & 0.001 \\
\hline & [0.013] & [0.012] \\
\hline \multirow[t]{2}{*}[\mathrm{T}1]{$+[\mathrm{T} 2]+$ Web. Assistance $[\mathrm{T} 4]$} & -0.019 & -0.006 \\
\hline & [0.012] & [0.008] \\
\hline \multirow[t]{2}{*}[\mathrm{T}1]{$+[\mathrm{T} 2]+[\mathrm{T} 3]+[\mathrm{T} 4]$ "All Information + Website" } & -0.015 & -0.001 \\
\hline & [0.013] & [0.009] \\
\hline \multirow[t]{2}{*}{ [T3] + [T5] "Only Passport Assistance" } & -0.014 & -0.002 \\
\hline & {$[0.017]$} & [0.014] \\
\hline \multirow[t]{2}{*}[T1]{$+[T 3]+[T 5]$} & $-0.025^{*}$ & -0.010 \\
\hline & {$[0.014]$} & [0.009] \\
\hline \multirow[t]{2}{*}[\mathrm{T}2]{$+[\mathrm{T} 3]+[\mathrm{T} 5]$} & -0.018 & -0.001 \\
\hline & [0.019] & [0.015] \\
\hline \multirow[t]{2}{*}[\mathrm{T}1]{$+[\mathrm{T} 2]+[\mathrm{T} 3]+[\mathrm{T} 5]$ "All Information + Passport" } & -0.019 & -0.006 \\
\hline & {$[0.020]$} & [0.013] \\
\hline \multirow[t]{2}{*}[\mathrm{T}1]{$+[\mathrm{T} 2]+[\mathrm{T} 3]+[\mathrm{T} 4]+[\mathrm{T} 5]$ "Full Assistance" } & 0.001 & 0.000 \\
\hline & [0.001] & {$[0.001]$} \\
\hline Sample Size & 4,089 & 3,802 \\
\hline Control group dependent variable mean & $1.1 \%$ & $1.0 \%$ \\
\hline$P$-value, coefficients jointly zero & 0.500 & 0.791 \\
\hline
\end{tabular}

*** $p<0.01,{ }^{* *} p<0.05,{ }^{*} p<0.10$

Column 1 sample includes baseline respondents with respondent, proxy, and log endline surveys and non-missing outcome variables. Column 2 migration outcome is based on 2010-2012 offers confirmed in 2013 follow-up survey, which was conducted among all households with at least one job offer overseas at 2012 endline. Stratification-cell fixed effects and baseline covariates described in Table 2 are included. Huber-White standard errors reported in brackets. 
Table A10: Impact of unilateral facilitation on overseas job search and migration, full set of coefficients from Table 2

\begin{tabular}{|c|c|c|c|c|c|c|c|c|}
\hline & \multicolumn{4}{|c|}{$\begin{array}{l}\text { From 2010-2012, did the respondent search } \\
\text { for work overseas by ... }\end{array}$} & \multicolumn{4}{|c|}{ From 2010-2012, did the respondent ... } \\
\hline & $\begin{array}{c}\text { Any way } \\
\text { (1) }\end{array}$ & $\begin{array}{c}\text { Using } \\
\text { Internet } \\
(2)\end{array}$ & $\begin{array}{l}\text { Visiting } \\
\text { recruitment } \\
\text { agency } \\
\text { (3) }\end{array}$ & $\begin{array}{l}\text { Some } \\
\text { other } \\
\text { way } \\
(4)\end{array}$ & $\begin{array}{c}\text { Receive } \\
\text { invitation } \\
\text { to } \\
\text { interview } \\
\text { (5) }\end{array}$ & $\begin{array}{l}\text { Attend } \\
\text { interview } \\
\text { (6) }\end{array}$ & $\begin{array}{l}\text { Receive } \\
\text { job offer } \\
\text { abroad } \\
\text { (7) }\end{array}$ & $\begin{array}{c}\text { Migrate } \\
\text { abroad } \\
\text { (8) }\end{array}$ \\
\hline Application Information [T1] & $\begin{array}{c}0.004 \\
{[0.013]}\end{array}$ & $\begin{array}{c}0.002 \\
{[0.006]}\end{array}$ & $\begin{array}{l}-0.008 \\
{[0.009]}\end{array}$ & $\begin{array}{c}0.011 \\
{[0.008]}\end{array}$ & $\begin{array}{c}0.005 \\
{[0.010]}\end{array}$ & $\begin{array}{c}0.013 \\
{[0.009]}\end{array}$ & $\begin{array}{c}0.004 \\
{[0.008]}\end{array}$ & $\begin{array}{c}-0.002 \\
{[0.005]}\end{array}$ \\
\hline Financial Information [T2] & $\begin{array}{c}-0.024 * * \\
{[0.012]}\end{array}$ & $\begin{array}{l}-0.004 \\
{[0.006]}\end{array}$ & $\begin{array}{l}-0.018^{* *} \\
{[0.009]}\end{array}$ & $\begin{array}{c}-0.002 \\
{[0.007]}\end{array}$ & $\begin{array}{c}-0.008 \\
{[0.009]}\end{array}$ & $\begin{array}{c}0.001 \\
{[0.008]}\end{array}$ & $\begin{array}{l}-0.000 \\
{[0.008]}\end{array}$ & $\begin{array}{l}-0.002 \\
{[0.005]}\end{array}$ \\
\hline Passport Information [T3] & $\begin{array}{l}-0.035^{*} \\
{[0.021]}\end{array}$ & $\begin{array}{c}-0.026 * * * \\
{[0.010]}\end{array}$ & $\begin{array}{c}-0.006 \\
{[0.018]}\end{array}$ & $\begin{array}{c}-0.009 \\
{[0.007]}\end{array}$ & $\begin{array}{c}-0.003 \\
{[0.018]}\end{array}$ & $\begin{array}{c}0.006 \\
{[0.017]}\end{array}$ & $\begin{array}{l}-0.005 \\
{[0.013]}\end{array}$ & $\begin{array}{c}0.006 \\
{[0.012]}\end{array}$ \\
\hline$[\mathrm{T} 1]+[\mathrm{T} 2]$ & $\begin{array}{c}0.001 \\
{[0.013]}\end{array}$ & $\begin{array}{l}-0.001 \\
{[0.006]}\end{array}$ & $\begin{array}{c}0.003 \\
{[0.010]}\end{array}$ & $\begin{array}{c}0.005 \\
{[0.008]}\end{array}$ & $\begin{array}{c}0.001 \\
{[0.009]}\end{array}$ & $\begin{array}{l}0.008 \\
{[0.008]}\end{array}$ & $\begin{array}{c}0.006 \\
{[0.008]}\end{array}$ & $\begin{array}{l}-0.003 \\
{[0.005]}\end{array}$ \\
\hline$[\mathrm{T} 1]+[\mathrm{T} 3]$ & $\begin{array}{c}0.014 \\
{[0.027]}\end{array}$ & $\begin{array}{l}-0.010 \\
{[0.014]}\end{array}$ & $\begin{array}{c}0.004 \\
{[0.020]}\end{array}$ & $\begin{array}{c}0.025 \\
{[0.018]}\end{array}$ & $\begin{array}{c}0.009 \\
{[0.020]}\end{array}$ & $\begin{array}{c}0.007 \\
{[0.016]}\end{array}$ & $\begin{array}{c}0.007 \\
{[0.016]}\end{array}$ & $\begin{array}{c}-0.005 \\
{[0.005]}\end{array}$ \\
\hline$[\mathrm{T} 2]+[\mathrm{T} 3]$ & $\begin{array}{c}0.010 \\
{[0.026]}\end{array}$ & $\begin{array}{c}-0.001 \\
{[0.016]}\end{array}$ & $\begin{array}{c}0.003 \\
{[0.020]}\end{array}$ & $\begin{array}{c}0.001 \\
{[0.013]}\end{array}$ & $\begin{array}{c}0.018 \\
{[0.023]}\end{array}$ & $\begin{array}{c}0.006 \\
{[0.017]}\end{array}$ & $\begin{array}{c}0.004 \\
{[0.017]}\end{array}$ & $\begin{array}{l}-0.007 \\
{[0.005]}\end{array}$ \\
\hline [T1] + [T2] +[T3] "All Information" & $\begin{array}{c}0.001 \\
{[0.025]}\end{array}$ & $\begin{array}{c}-0.010 \\
{[0.013]}\end{array}$ & $\begin{array}{c}0.002 \\
{[0.019]}\end{array}$ & $\begin{array}{c}0.014 \\
{[0.015]}\end{array}$ & $\begin{array}{c}0.028 \\
{[0.023]}\end{array}$ & $\begin{array}{c}0.026 \\
{[0.021]}\end{array}$ & $\begin{array}{c}0.004 \\
{[0.016]}\end{array}$ & $\begin{array}{c}0.004 \\
{[0.011]}\end{array}$ \\
\hline$[\mathrm{T} 1]+[\mathrm{T} 2]+$ Web. Assistance [T4] & $\begin{array}{c}0.104^{* * *} \\
{[0.026]}\end{array}$ & $\begin{array}{c}0.103 * * * \\
{[0.022]}\end{array}$ & $\begin{array}{c}-0.015 \\
{[0.013]}\end{array}$ & $\begin{array}{c}0.019 \\
{[0.012]}\end{array}$ & $\begin{array}{c}0.011 \\
{[0.015]}\end{array}$ & $\begin{array}{c}0.001 \\
{[0.012]}\end{array}$ & $\begin{array}{c}0.004 \\
{[0.012]}\end{array}$ & $\begin{array}{c}-0.003 \\
{[0.006]}\end{array}$ \\
\hline$[T 1]+[T 2]+[T 3]+[T 4]$ "All Information + Website" & $\begin{array}{c}0.106^{* * *} \\
{[0.025]}\end{array}$ & $\begin{array}{c}0.100 * * * \\
{[0.022]}\end{array}$ & $\begin{array}{c}0.001 \\
{[0.014]}\end{array}$ & $\begin{array}{c}0.012 \\
{[0.010]}\end{array}$ & $\begin{array}{c}0.018 \\
{[0.015]}\end{array}$ & $\begin{array}{c}0.022 \\
{[0.013]}\end{array}$ & $\begin{array}{c}0.009 \\
{[0.012]}\end{array}$ & $\begin{array}{c}0.002 \\
{[0.007]}\end{array}$ \\
\hline [T3] + [T5] "Only Passport Assistance" & $\begin{array}{c}0.074 * * \\
{[0.037]}\end{array}$ & $\begin{array}{c}0.005 \\
{[0.021]}\end{array}$ & $\begin{array}{c}0.031 \\
{[0.026]}\end{array}$ & $\begin{array}{c}0.054^{* *} \\
{[0.026]}\end{array}$ & $\begin{array}{c}0.024 \\
{[0.025]}\end{array}$ & $\begin{array}{c}0.024 \\
{[0.022]}\end{array}$ & $\begin{array}{c}0.013 \\
{[0.020]}\end{array}$ & $\begin{array}{c}0.003 \\
{[0.012]}\end{array}$ \\
\hline$[\mathrm{T} 1]+[\mathrm{T} 3]+[\mathrm{T} 5]$ & $\begin{array}{c}0.035 \\
{[0.031]}\end{array}$ & $\begin{array}{l}0.043^{*} \\
{[0.025]}\end{array}$ & $\begin{array}{c}0.002 \\
{[0.021]}\end{array}$ & $\begin{array}{c}0.005 \\
{[0.013]}\end{array}$ & $\begin{array}{c}0.028 \\
{[0.025]}\end{array}$ & $\begin{array}{c}0.006 \\
{[0.018]}\end{array}$ & $\begin{array}{c}-0.004 \\
{[0.014]}\end{array}$ & $\begin{array}{l}-0.005 \\
{[0.005]}\end{array}$ \\
\hline$[\mathrm{T} 2]+[\mathrm{T} 3]+[\mathrm{T} 5]$ & $\begin{array}{c}0.042 \\
{[0.031]}\end{array}$ & $\begin{array}{c}0.008 \\
{[0.020]}\end{array}$ & $\begin{array}{c}0.033 \\
{[0.026]}\end{array}$ & $\begin{array}{c}0.006 \\
{[0.013]}\end{array}$ & $\begin{array}{c}0.039 \\
{[0.026]}\end{array}$ & $\begin{array}{l}0.038^{*} \\
{[0.023]}\end{array}$ & $\begin{array}{c}0.026 \\
{[0.021]}\end{array}$ & $\begin{array}{c}0.004 \\
{[0.012]}\end{array}$ \\
\hline$[T 1]+[T 2]+[T 3]+[T 5]$ "All Information + Passport" & $\begin{array}{c}0.043 \\
{[0.029]}\end{array}$ & $\begin{array}{l}-0.006 \\
{[0.014]}\end{array}$ & $\begin{array}{c}0.039 \\
{[0.025]}\end{array}$ & $\begin{array}{c}0.028 \\
{[0.019]}\end{array}$ & $\begin{array}{l}0.044^{*} \\
{[0.026]}\end{array}$ & $\begin{array}{c}0.030 \\
{[0.022]}\end{array}$ & $\begin{array}{c}0.008 \\
{[0.017]}\end{array}$ & $\begin{array}{c}0.016 \\
{[0.016]}\end{array}$ \\
\hline$[\mathrm{T} 1]+[\mathrm{T} 2]+[\mathrm{T} 3]+[\mathrm{T} 4]+[\mathrm{T} 5]$ "Full Assistance" & $\begin{array}{c}0.159 * * * \\
{[0.028]}\end{array}$ & $\begin{array}{c}0.145^{* * *} \\
{[0.024]}\end{array}$ & $\begin{array}{c}0.015 \\
{[0.016]}\end{array}$ & $\begin{array}{c}0.027^{* *} \\
{[0.013]} \\
\end{array}$ & $\begin{array}{l}0.031^{*} \\
{[0.017]}\end{array}$ & $\begin{array}{c}0.032^{* *} \\
{[0.015]} \\
\end{array}$ & $\begin{array}{l}0.028^{*} \\
{[0.015]}\end{array}$ & $\begin{array}{c}0.000 \\
{[0.007]}\end{array}$ \\
\hline Sample Size & 3,802 & 3,802 & 3,802 & 3,802 & 3,802 & 3,802 & 3,802 & 3,802 \\
\hline Control group dependent variable mean & $5.1 \%$ & $1.0 \%$ & $2.9 \%$ & $1.4 \%$ & $2.6 \%$ & $1.5 \%$ & $1.7 \%$ & $0.9 \%$ \\
\hline$P$-value, coefficients jointly zero & $0.000 * * *$ & $0.000 * * *$ & 0.261 & $0.020 * *$ & 0.539 & 0.546 & 0.922 & 0.699 \\
\hline
\end{tabular}

Same specification as Table 2, reporting full set of treatment indicators. Sample includes baseline respondents with completed endline surveys. Stratification-cell fixed effects and baseline covariates described in Table 2 are included. Huber-White standard errors reported in brackets. 
Table A11: Impacts for the subgroup expressing interest in migrating abroad at baseline, full set of coefficients from Table 3

\begin{tabular}{|c|c|c|c|c|c|c|c|c|}
\hline & \multicolumn{4}{|c|}{$\begin{array}{l}\text { From 2010-2012, did the respondent search } \\
\text { for work overseas by ... }\end{array}$} & \multicolumn{4}{|c|}{ From 2010-2012, did the respondent ... } \\
\hline & (1) & $\begin{array}{c}\text { Using } \\
\text { Internet } \\
\text { (2) }\end{array}$ & $\begin{array}{c}\text { Visiting } \\
\text { recruitment } \\
\text { agency } \\
\text { (3) }\end{array}$ & $\begin{array}{c}\text { Some } \\
\text { other } \\
\text { way } \\
(4)\end{array}$ & $\begin{array}{c}\text { Receive } \\
\text { invitation } \\
\text { to } \\
\text { interview } \\
\text { (5) }\end{array}$ & $\begin{array}{c}\text { Attend } \\
\text { interview } \\
\text { (6) }\end{array}$ & $\begin{array}{c}\text { Receive } \\
\text { job offer } \\
\text { abroad } \\
(7)\end{array}$ & $\begin{array}{c}\text { Migrate } \\
\text { abroad } \\
\text { (8) }\end{array}$ \\
\hline Application Information [T1] & $\begin{array}{c}0.017 \\
{[0.037]}\end{array}$ & $\begin{array}{c}0.020 \\
{[0.018]}\end{array}$ & $\begin{array}{c}-0.015 \\
{[0.027]}\end{array}$ & $\begin{array}{c}0.025 \\
{[0.023]}\end{array}$ & $\begin{array}{c}0.021 \\
{[0.029]}\end{array}$ & $\begin{array}{c}0.039 \\
{[0.024]}\end{array}$ & $\begin{array}{c}0.019 \\
{[0.024]}\end{array}$ & $\begin{array}{c}0.010 \\
{[0.016]}\end{array}$ \\
\hline Financial Information [T2] & $\begin{array}{l}-0.033 \\
{[0.032]}\end{array}$ & $\begin{array}{c}0.013 \\
{[0.017]}\end{array}$ & $\begin{array}{c}-0.028 \\
{[0.024]}\end{array}$ & $\begin{array}{l}-0.004 \\
{[0.019]}\end{array}$ & $\begin{array}{l}-0.006 \\
{[0.026]}\end{array}$ & $\begin{array}{c}0.017 \\
{[0.022]}\end{array}$ & $\begin{array}{c}0.009 \\
{[0.022]}\end{array}$ & $\begin{array}{c}0.009 \\
{[0.014]}\end{array}$ \\
\hline Passport Information [T3] & $\begin{array}{l}-0.029 \\
{[0.053]}\end{array}$ & $\begin{array}{c}-0.036 \\
{[0.026]}\end{array}$ & $\begin{array}{c}0.026 \\
{[0.045]}\end{array}$ & $\begin{array}{l}-0.024 \\
{[0.023]}\end{array}$ & $\begin{array}{c}0.033 \\
{[0.046]}\end{array}$ & $\begin{array}{c}0.052 \\
{[0.042]}\end{array}$ & $\begin{array}{c}0.013 \\
{[0.033]}\end{array}$ & $\begin{array}{c}0.030 \\
{[0.026]}\end{array}$ \\
\hline$[\mathrm{T} 1]+[\mathrm{T} 2]$ & $\begin{array}{c}0.032 \\
{[0.038]}\end{array}$ & $\begin{array}{c}0.011 \\
{[0.018]}\end{array}$ & $\begin{array}{c}0.013 \\
{[0.030]}\end{array}$ & $\begin{array}{c}0.028 \\
{[0.023]}\end{array}$ & $\begin{array}{c}0.015 \\
{[0.029]}\end{array}$ & $\begin{array}{c}0.034 \\
{[0.025]}\end{array}$ & $\begin{array}{c}0.024 \\
{[0.026]}\end{array}$ & $\begin{array}{c}-0.005 \\
{[0.014]}\end{array}$ \\
\hline$[\mathrm{T} 1]+[\mathrm{T} 3]$ & $\begin{array}{c}0.077 \\
{[0.080]}\end{array}$ & $\begin{array}{c}-0.032 \\
{[0.041]}\end{array}$ & $\begin{array}{c}0.059 \\
{[0.059]}\end{array}$ & $\begin{array}{c}0.072 \\
{[0.057]}\end{array}$ & $\begin{array}{c}0.054 \\
{[0.060]}\end{array}$ & $\begin{array}{c}0.051 \\
{[0.048]}\end{array}$ & $\begin{array}{c}0.043 \\
{[0.047]}\end{array}$ & $\begin{array}{c}0.008 \\
{[0.012]}\end{array}$ \\
\hline$[\mathrm{T} 2]+[\mathrm{T} 3]$ & $\begin{array}{c}0.041 \\
{[0.061]}\end{array}$ & $\begin{array}{c}-0.006 \\
{[0.036]}\end{array}$ & $\begin{array}{c}0.035 \\
{[0.048]}\end{array}$ & $\begin{array}{c}0.007 \\
{[0.032]}\end{array}$ & $\begin{array}{c}0.059 \\
{[0.053]}\end{array}$ & $\begin{array}{c}0.034 \\
{[0.040]}\end{array}$ & $\begin{array}{c}0.031 \\
{[0.040]}\end{array}$ & $\begin{array}{c}-0.002 \\
{[0.013]}\end{array}$ \\
\hline [T1] + [T2] +[T3] "All Information" & $\begin{array}{c}0.050 \\
{[0.065]}\end{array}$ & $\begin{array}{c}0.004 \\
{[0.036]}\end{array}$ & $\begin{array}{c}0.034 \\
{[0.052]}\end{array}$ & $\begin{array}{c}0.032 \\
{[0.041]}\end{array}$ & $\begin{array}{c}0.104^{*} \\
{[0.062]}\end{array}$ & $\begin{array}{l}0.095^{*} \\
{[0.056]}\end{array}$ & $\begin{array}{c}0.035 \\
{[0.043]}\end{array}$ & $\begin{array}{c}0.026 \\
{[0.028]}\end{array}$ \\
\hline$[\mathrm{T} 1]+[\mathrm{T} 2]+$ Web. Assistance [T4] & $\begin{array}{c}0.197^{* * *} \\
{[0.060]}\end{array}$ & $\begin{array}{c}0.185^{* * *} \\
{[0.048]}\end{array}$ & $\begin{array}{c}-0.006 \\
{[0.034]}\end{array}$ & $\begin{array}{c}0.035 \\
{[0.031]}\end{array}$ & $\begin{array}{c}0.032 \\
{[0.040]}\end{array}$ & $\begin{array}{c}0.015 \\
{[0.031]}\end{array}$ & $\begin{array}{c}0.012 \\
{[0.031]}\end{array}$ & $\begin{array}{c}0.009 \\
{[0.016]}\end{array}$ \\
\hline$[T 1]+[T 2]+[T 3]+[T 4]$ "All Information + Website" & $\begin{array}{c}0.196 * * * \\
{[0.059]}\end{array}$ & $\begin{array}{c}0.167 * * * \\
{[0.049]}\end{array}$ & $\begin{array}{c}0.018 \\
{[0.035]}\end{array}$ & $\begin{array}{c}0.025 \\
{[0.029]}\end{array}$ & $\begin{array}{c}0.069^{*} \\
{[0.040]}\end{array}$ & $\begin{array}{c}0.077^{* *} \\
{[0.037]}\end{array}$ & $\begin{array}{c}0.041 \\
{[0.033]}\end{array}$ & $\begin{array}{c}0.023 \\
{[0.021]}\end{array}$ \\
\hline [T3] + [T5] "Only Passport Assistance" & $\begin{array}{c}0.172 * * \\
{[0.082]}\end{array}$ & $\begin{array}{c}0.009 \\
{[0.041]}\end{array}$ & $\begin{array}{c}0.078 \\
{[0.058]}\end{array}$ & $\begin{array}{c}0.139 * * \\
{[0.062]}\end{array}$ & $\begin{array}{c}0.082 \\
{[0.063]}\end{array}$ & $\begin{array}{c}0.079 \\
{[0.055]}\end{array}$ & $\begin{array}{c}0.047 \\
{[0.049]}\end{array}$ & $\begin{array}{c}0.019 \\
{[0.031]}\end{array}$ \\
\hline$[\mathrm{T} 1]+[\mathrm{T} 3]+[\mathrm{T} 5]$ & $\begin{array}{c}0.092 \\
{[0.081]}\end{array}$ & $\begin{array}{c}0.126^{*} \\
{[0.070]}\end{array}$ & $\begin{array}{c}0.016 \\
{[0.052]}\end{array}$ & $\begin{array}{c}0.010 \\
{[0.041]}\end{array}$ & $\begin{array}{c}0.037 \\
{[0.063]}\end{array}$ & $\begin{array}{c}-0.002 \\
{[0.044]}\end{array}$ & $\begin{array}{c}-0.004 \\
{[0.042]}\end{array}$ & $\begin{array}{c}-0.007 \\
{[0.014]}\end{array}$ \\
\hline$[\mathrm{T} 2]+[\mathrm{T} 3]+[\mathrm{T} 5]$ & $\begin{array}{c}0.087 \\
{[0.072]}\end{array}$ & $\begin{array}{c}0.004 \\
{[0.055]}\end{array}$ & $\begin{array}{c}0.073 \\
{[0.056]}\end{array}$ & $\begin{array}{c}0.021 \\
{[0.034]}\end{array}$ & $\begin{array}{c}0.069 \\
{[0.057]}\end{array}$ & $\begin{array}{c}0.073 \\
{[0.048]}\end{array}$ & $\begin{array}{c}0.065 \\
{[0.047]}\end{array}$ & $\begin{array}{c}0.029 \\
{[0.030]}\end{array}$ \\
\hline$[T 1]+[T 2]+[T 3]+[T 5]$ "All Information + Passport" & $\begin{array}{c}0.199^{* *} \\
{[0.094]}\end{array}$ & $\begin{array}{c}0.000 \\
{[0.044]}\end{array}$ & $\begin{array}{c}0.177^{* *} \\
{[0.082]}\end{array}$ & $\begin{array}{c}0.091 \\
{[0.064]}\end{array}$ & $\begin{array}{c}0.177^{* *} \\
{[0.084]}\end{array}$ & $\begin{array}{c}0.120 \\
{[0.074]}\end{array}$ & $\begin{array}{c}0.048 \\
{[0.059]}\end{array}$ & $\begin{array}{c}0.066 \\
{[0.055]}\end{array}$ \\
\hline$[T 1]+[T 2]+[T 3]+[T 4]+[T 5]$ "Full Assistance" & $\begin{array}{c}0.266^{* * *} \\
{[0.060]}\end{array}$ & $\begin{array}{c}0.222^{* * *} \\
{[0.050]}\end{array}$ & $\begin{array}{c}0.042 \\
{[0.037]} \\
\end{array}$ & $\begin{array}{c}0.049 \\
{[0.031]} \\
\end{array}$ & $\begin{array}{l}0.074 * \\
{[0.041]} \\
\end{array}$ & $\begin{array}{c}0.085^{* *} \\
{[0.037]} \\
\end{array}$ & $\begin{array}{r}0.073^{* *} \\
{[0.035]} \\
\end{array}$ & $\begin{array}{c}0.017 \\
{[0.017]}\end{array}$ \\
\hline Sample Size & 1,292 & 1,292 & 1,292 & 1,292 & 1,292 & 1,292 & 1,292 & 1,292 \\
\hline Control group dependent variable mean & $11.0 \%$ & $1.7 \%$ & $6.6 \%$ & $2.8 \%$ & $6.0 \%$ & $3.3 \%$ & $3.9 \%$ & $1.7 \%$ \\
\hline$P$-value, coefficients jointly zero & $0.000 * * *$ & $0.000 * * *$ & 0.506 & $0.066^{*}$ & 0.632 & 0.401 & 0.890 & 0.698 \\
\hline
\end{tabular}

Same specification as Table 3, reporting full set of treatment indicators. Sample includes baseline respondents with completed endline surveys. Stratification-cell fixed effects and baseline covariates described in Table 2 are included. Huber-White standard errors reported in brackets 
Table A12: Impact of unilateral facilitation on overseas job-search and migration, including respondents ages 41-45

\begin{tabular}{|c|c|c|c|c|c|c|c|c|}
\hline & \multicolumn{4}{|c|}{$\begin{array}{l}\text { From 2010-2012, did the respondent search } \\
\text { for work overseas by ... }\end{array}$} & \multicolumn{4}{|c|}{ From 2010-2012, did the respondent ... } \\
\hline & $\begin{array}{c}\text { Any way } \\
\text { (1) }\end{array}$ & $\begin{array}{c}\text { Using } \\
\text { Internet } \\
(2)\end{array}$ & $\begin{array}{c}\text { Visiting } \\
\text { recruitment } \\
\text { agency } \\
\text { (3) }\end{array}$ & $\begin{array}{c}\text { Some } \\
\text { other } \\
\text { way } \\
(4)\end{array}$ & $\begin{array}{c}\text { Receive } \\
\text { invitation } \\
\text { to } \\
\text { interview } \\
\text { (5) }\end{array}$ & $\begin{array}{c}\text { Attend } \\
\text { interview } \\
\text { (6) }\end{array}$ & $\begin{array}{c}\text { Receive } \\
\text { job offer } \\
\text { abroad } \\
\text { (7) }\end{array}$ & $\begin{array}{c}\text { Migrate } \\
\text { abroad } \\
\text { (8) }\end{array}$ \\
\hline Application Information [T1] & $\begin{array}{c}0.002 \\
{[0.011]}\end{array}$ & $\begin{array}{c}0.001 \\
{[0.005]}\end{array}$ & $\begin{array}{c}-0.007 \\
{[0.008]}\end{array}$ & $\begin{array}{c}0.010 \\
{[0.006]}\end{array}$ & $\begin{array}{c}0.005 \\
{[0.008]}\end{array}$ & $\begin{array}{c}0.011 \\
{[0.007]}\end{array}$ & $\begin{array}{c}0.003 \\
{[0.006]}\end{array}$ & $\begin{array}{c}-0.001 \\
{[0.004]}\end{array}$ \\
\hline Financial Information [T2] & $\begin{array}{l}-0.018^{*} \\
{[0.010]}\end{array}$ & $\begin{array}{l}-0.004 \\
{[0.005]}\end{array}$ & $\begin{array}{c}-0.016^{* *} \\
{[0.007]}\end{array}$ & $\begin{array}{l}0.002 \\
{[0.006]}\end{array}$ & $\begin{array}{l}-0.006 \\
{[0.007]}\end{array}$ & $\begin{array}{c}0.002 \\
{[0.006]}\end{array}$ & $\begin{array}{l}0.002 \\
{[0.006]}\end{array}$ & $\begin{array}{l}-0.001 \\
{[0.004]}\end{array}$ \\
\hline Passport Information [T3] & $\begin{array}{c}-0.050 * * \\
{[0.020]}\end{array}$ & $\begin{array}{c}-0.043^{* * *} \\
{[0.009]}\end{array}$ & $\begin{array}{c}-0.003 \\
{[0.017]}\end{array}$ & $\begin{array}{c}-0.009 \\
{[0.007]}\end{array}$ & $\begin{array}{c}-0.006 \\
{[0.017]}\end{array}$ & $\begin{array}{c}0.005 \\
{[0.017]}\end{array}$ & $\begin{array}{c}-0.005 \\
{[0.013]}\end{array}$ & $\begin{array}{c}0.006 \\
{[0.011]}\end{array}$ \\
\hline$[\mathrm{T} 1]+[\mathrm{T} 2]$ & $\begin{array}{l}-0.001 \\
{[0.011]}\end{array}$ & $\begin{array}{c}-0.001 \\
{[0.005]}\end{array}$ & $\begin{array}{l}0.002 \\
{[0.008]}\end{array}$ & $\begin{array}{c}0.003 \\
{[0.006]}\end{array}$ & $\begin{array}{l}-0.001 \\
{[0.008]}\end{array}$ & $\begin{array}{c}0.004 \\
{[0.007]}\end{array}$ & $\begin{array}{c}0.005 \\
{[0.007]}\end{array}$ & $\begin{array}{l}-0.001 \\
{[0.004]}\end{array}$ \\
\hline$[\mathrm{T} 1]+[\mathrm{T} 3]$ & $\begin{array}{l}-0.003 \\
{[0.026]}\end{array}$ & $\begin{array}{c}-0.028^{* *} \\
{[0.013]}\end{array}$ & $\begin{array}{c}0.008 \\
{[0.019]}\end{array}$ & $\begin{array}{c}0.024 \\
{[0.018]}\end{array}$ & $\begin{array}{c}0.005 \\
{[0.019]}\end{array}$ & $\begin{array}{c}0.006 \\
{[0.016]}\end{array}$ & $\begin{array}{l}0.006 \\
{[0.015]}\end{array}$ & $\begin{array}{l}-0.005 \\
{[0.004]}\end{array}$ \\
\hline$[\mathrm{T} 2]+[\mathrm{T} 3]$ & $\begin{array}{l}-0.007 \\
{[0.026]}\end{array}$ & $\begin{array}{l}-0.018 \\
{[0.016]}\end{array}$ & $\begin{array}{l}0.006 \\
{[0.020]}\end{array}$ & $\begin{array}{c}0.001 \\
{[0.012]}\end{array}$ & $\begin{array}{c}0.015 \\
{[0.022]}\end{array}$ & $\begin{array}{c}0.004 \\
{[0.017]}\end{array}$ & $\begin{array}{c}0.004 \\
{[0.017]}\end{array}$ & $\begin{array}{l}-0.006 \\
{[0.004]}\end{array}$ \\
\hline$[\mathrm{T} 1]+[\mathrm{T} 2]+[\mathrm{T} 3]$ "All Information" & $\begin{array}{c}-0.016 \\
{[0.024]}\end{array}$ & $\begin{array}{c}-0.027^{* *} \\
{[0.013]}\end{array}$ & $\begin{array}{c}0.005 \\
{[0.019]}\end{array}$ & $\begin{array}{c}0.013 \\
{[0.015]}\end{array}$ & $\begin{array}{c}0.025 \\
{[0.023]}\end{array}$ & $\begin{array}{c}0.025 \\
{[0.021]}\end{array}$ & $\begin{array}{c}0.004 \\
{[0.016]}\end{array}$ & $\begin{array}{c}0.005 \\
{[0.011]}\end{array}$ \\
\hline$[\mathrm{T} 1]+[\mathrm{T} 2]+$ Web. Assistance $[\mathrm{T} 4]$ & $\begin{array}{c}0.060 * * * \\
{[0.016]}\end{array}$ & $\begin{array}{c}0.059 * * * \\
{[0.013]}\end{array}$ & $\begin{array}{c}-0.006 \\
{[0.009]}\end{array}$ & $\begin{array}{r}0.017 * * \\
{[0.008]}\end{array}$ & $\begin{array}{c}0.004 \\
{[0.009]}\end{array}$ & $\begin{array}{c}-0.000 \\
{[0.007]}\end{array}$ & $\begin{array}{c}0.003 \\
{[0.007]}\end{array}$ & $\begin{array}{l}-0.002 \\
{[0.004]}\end{array}$ \\
\hline$[\mathrm{T} 1]+[\mathrm{T} 2]+[\mathrm{T} 3]+[\mathrm{T} 4]$ "All Information + Website" & $\begin{array}{c}0.090 * * * \\
{[0.024]}\end{array}$ & $\begin{array}{c}0.083 * * * \\
{[0.022]}\end{array}$ & $\begin{array}{c}0.004 \\
{[0.013]}\end{array}$ & $\begin{array}{c}0.012 \\
{[0.010]}\end{array}$ & $\begin{array}{c}0.015 \\
{[0.014]}\end{array}$ & $\begin{array}{c}0.020 \\
{[0.013]}\end{array}$ & $\begin{array}{c}0.008 \\
{[0.011]}\end{array}$ & $\begin{array}{c}0.003 \\
{[0.007]}\end{array}$ \\
\hline [T3] + [T5] "Only Passport Assistance" & $\begin{array}{c}0.059 \\
{[0.036]}\end{array}$ & $\begin{array}{c}-0.011 \\
{[0.020]}\end{array}$ & $\begin{array}{c}0.035 \\
{[0.026]}\end{array}$ & $\begin{array}{r}0.053^{* *} \\
{[0.026]}\end{array}$ & $\begin{array}{c}0.021 \\
{[0.024]}\end{array}$ & $\begin{array}{c}0.022 \\
{[0.022]}\end{array}$ & $\begin{array}{c}0.012 \\
{[0.019]}\end{array}$ & $\begin{array}{c}0.004 \\
{[0.011]}\end{array}$ \\
\hline$[\mathrm{T} 1]+[\mathrm{T} 3]+[\mathrm{T} 5]$ & $\begin{array}{c}0.017 \\
{[0.030]}\end{array}$ & $\begin{array}{c}0.025 \\
{[0.025]}\end{array}$ & $\begin{array}{c}0.005 \\
{[0.020]}\end{array}$ & $\begin{array}{c}0.004 \\
{[0.012]}\end{array}$ & $\begin{array}{c}0.025 \\
{[0.024]}\end{array}$ & $\begin{array}{c}0.005 \\
{[0.017]}\end{array}$ & $\begin{array}{c}-0.005 \\
{[0.013]}\end{array}$ & $\begin{array}{c}-0.005 \\
{[0.004]}\end{array}$ \\
\hline$[\mathrm{T} 2]+[\mathrm{T} 3]+[\mathrm{T} 5]$ & $\begin{array}{c}0.025 \\
{[0.031]}\end{array}$ & $\begin{array}{c}-0.010 \\
{[0.020]}\end{array}$ & $\begin{array}{c}0.036 \\
{[0.025]}\end{array}$ & $\begin{array}{c}0.005 \\
{[0.012]}\end{array}$ & $\begin{array}{c}0.035 \\
{[0.025]}\end{array}$ & $\begin{array}{c}0.036 \\
{[0.023]}\end{array}$ & $\begin{array}{c}0.025 \\
{[0.021]}\end{array}$ & $\begin{array}{c}0.005 \\
{[0.011]}\end{array}$ \\
\hline$[\mathrm{T} 1]+[\mathrm{T} 2]+[\mathrm{T} 3]+[\mathrm{T} 5]$ "All Information + Passport" & $\begin{array}{c}0.025 \\
{[0.028]}\end{array}$ & $\begin{array}{c}-0.024^{*} \\
{[0.013]}\end{array}$ & $\begin{array}{l}0.042^{*} \\
{[0.025]}\end{array}$ & $\begin{array}{c}0.026 \\
{[0.019]}\end{array}$ & $\begin{array}{c}0.040 \\
{[0.025]}\end{array}$ & $\begin{array}{c}0.028 \\
{[0.021]}\end{array}$ & $\begin{array}{c}0.007 \\
{[0.016]}\end{array}$ & $\begin{array}{c}0.016 \\
{[0.015]}\end{array}$ \\
\hline$[\mathrm{T} 1]+[\mathrm{T} 2]+[\mathrm{T} 3]+[\mathrm{T} 4]+[\mathrm{T} 5]$ "Full Assistance" & $\begin{array}{c}0.142 * * * \\
{[0.027]}\end{array}$ & $\begin{array}{c}0.128 * * * \\
{[0.024]}\end{array}$ & $\begin{array}{c}0.018 \\
{[0.015]}\end{array}$ & $\begin{array}{r}0.026^{* *} \\
{[0.013]}\end{array}$ & $\begin{array}{l}0.028^{*} \\
{[0.016]}\end{array}$ & $\begin{array}{c}0.031 * * \\
{[0.015]}\end{array}$ & $\begin{array}{l}0.028^{*} \\
{[0.014]}\end{array}$ & $\begin{array}{c}0.001 \\
{[0.007]}\end{array}$ \\
\hline Sample Size & 4,596 & 4,596 & 4,596 & 4,596 & 4,596 & 4,596 & 4,596 & 4,596 \\
\hline Control group dependent variable mean & $4.4 \%$ & $0.9 \%$ & $2.5 \%$ & $1.1 \%$ & $2.1 \%$ & $1.3 \%$ & $1.3 \%$ & $0.7 \%$ \\
\hline P-value, coefficients jointly zero & $0.000 * * *$ & $0.000 * * *$ & 0.233 & $0.009 * * *$ & 0.615 & 0.571 & 0.924 & 0.654 \\
\hline
\end{tabular}

Sample includes baseline respondents (ages 20-45) with completed endline surveys. Stratification-cell fixed effects and baseline covariates described in Table 2 are included. Huber-White standard errors reported in brackets. 
Table A13: Impacts for the subgroup expressing interest in migrating abroad at baseline, including respondents ages 41-45

\begin{tabular}{|c|c|c|c|c|c|c|c|c|}
\hline & \multicolumn{4}{|c|}{$\begin{array}{l}\text { From 2010-2012, did the respondent search } \\
\text { for work overseas by ... }\end{array}$} & \multicolumn{4}{|c|}{ From 2010-2012, did the respondent ... } \\
\hline & Any way & $\begin{array}{l}\text { Using } \\
\text { Internet } \\
(2)\end{array}$ & $\begin{array}{l}\text { Visiting } \\
\text { recruitment } \\
\text { agency } \\
\text { (3) }\end{array}$ & $\begin{array}{l}\text { Some } \\
\text { other } \\
\text { way } \\
\text { (4) }\end{array}$ & $\begin{array}{c}\text { Receive } \\
\text { invitation } \\
\text { to } \\
\text { interview } \\
\text { (5) }\end{array}$ & $\begin{array}{c}\text { Attend } \\
\text { interview } \\
\text { (6) }\end{array}$ & $\begin{array}{c}\text { Receive } \\
\text { job offer } \\
\text { abroad } \\
\text { (7) }\end{array}$ & $\begin{array}{c}\text { Migrate } \\
\text { abroad } \\
\text { (8) }\end{array}$ \\
\hline \multirow[t]{2}{*}{ Application Information [T1] } & 0.016 & 0.012 & -0.009 & 0.026 & 0.023 & $0.037^{*}$ & 0.018 & 0.010 \\
\hline & {$[0.032]$} & [0.016] & {$[0.024]$} & {$[0.020]$} & {$[0.026]$} & {$[0.022]$} & {$[0.020]$} & [0.013] \\
\hline \multirow[t]{2}{*}{ Financial Information [T2] } & -0.036 & 0.006 & -0.023 & -0.004 & -0.008 & 0.012 & 0.008 & 0.009 \\
\hline & [0.029] & [0.016] & {$[0.022]$} & {$[0.016]$} & {$[0.023]$} & {$[0.020]$} & [0.019] & [0.012] \\
\hline \multirow[t]{2}{*}{ Passport Information [T3] } & -0.056 & $-0.064 * * *$ & 0.029 & -0.022 & 0.021 & 0.041 & 0.011 & 0.028 \\
\hline & {$[0.051]$} & [0.024] & {$[0.044]$} & {$[0.020]$} & {$[0.045]$} & {$[0.042]$} & [0.031] & [0.026] \\
\hline \multirow[t]{2}{*}[\mathrm{T}1]{$+[\mathrm{T} 2]$} & 0.029 & 0.010 & 0.013 & 0.021 & 0.006 & 0.021 & 0.020 & -0.002 \\
\hline & [0.033] & {$[0.016]$} & {$[0.026]$} & {$[0.019]$} & {$[0.024]$} & {$[0.022]$} & {$[0.021]$} & [0.011] \\
\hline \multirow[t]{2}{*}[\mathrm{T}1]{$+[\mathrm{T} 3]$} & 0.056 & -0.059 & 0.067 & 0.079 & 0.048 & 0.045 & 0.042 & 0.005 \\
\hline & {$[0.078]$} & {$[0.040]$} & [0.057] & {$[0.056]$} & {$[0.058]$} & [0.047] & {$[0.046]$} & [0.011] \\
\hline \multirow[t]{2}{*}[\mathrm{T}2]{$+[\mathrm{T} 3]$} & 0.018 & -0.034 & 0.042 & 0.012 & 0.053 & 0.028 & 0.030 & -0.003 \\
\hline & [0.059] & [0.035] & [0.047] & {$[0.031]$} & {$[0.052]$} & [0.039] & [0.039] & [0.011] \\
\hline \multirow[t]{2}{*}[\mathrm{T}1]{$+[\mathrm{T} 2]+[\mathrm{T} 3]$ "All Information" } & 0.029 & -0.025 & 0.042 & 0.039 & 0.100 & 0.091 & 0.034 & 0.025 \\
\hline & [0.065] & [0.035] & [0.051] & [0.041] & [0.062] & {$[0.057]$} & [0.042] & [0.028] \\
\hline \multirow[t]{2}{*}[\mathrm{T}1]{$+[\mathrm{T} 2]+$ Web. Assistance $[\mathrm{T} 4]$} & $0.142 * * *$ & $0.125^{* * *}$ & 0.008 & $0.047^{*}$ & 0.021 & 0.009 & 0.014 & 0.006 \\
\hline & [0.046] & [0.035] & [0.029] & {$[0.027]$} & {$[0.030]$} & {$[0.024]$} & {$[0.022]$} & [0.012] \\
\hline \multirow[t]{2}{*}[T1]{$+[T 2]+[T 3]+[T 4]$ "All Information + Website" } & $0.174 * * *$ & $0.139 * * *$ & 0.027 & 0.029 & 0.061 & $0.070 * *$ & 0.040 & 0.021 \\
\hline & [0.057] & [0.048] & [0.034] & [0.028] & [0.038] & {$[0.035]$} & {$[0.031]$} & [0.020] \\
\hline \multirow[t]{2}{*}{ [T3] + [T5] "Only Passport Assistance" } & $0.153^{*}$ & -0.018 & 0.088 & $0.143^{* *}$ & 0.078 & 0.076 & 0.048 & 0.019 \\
\hline & {$[0.081]$} & {$[0.041]$} & {$[0.057]$} & [0.062] & {$[0.061]$} & {$[0.053]$} & {$[0.048]$} & [0.030] \\
\hline \multirow[t]{2}{*}[\mathrm{T}1]{$+[\mathrm{T} 3]+[\mathrm{T} 5]$} & 0.066 & 0.098 & 0.021 & 0.015 & 0.032 & -0.007 & -0.005 & -0.008 \\
\hline & [0.079] & [0.069] & [0.051] & {$[0.040]$} & {$[0.061]$} & {$[0.042]$} & {$[0.041]$} & [0.013] \\
\hline \multirow[t]{2}{*}[\mathrm{T}2]{$+[\mathrm{T} 3]+[\mathrm{T} 5]$} & 0.061 & -0.019 & 0.078 & 0.021 & 0.060 & 0.065 & 0.063 & 0.027 \\
\hline & {$[0.070]$} & {$[0.054]$} & [0.054] & {$[0.033]$} & {$[0.055]$} & [0.047] & {$[0.045]$} & [0.030] \\
\hline \multirow[t]{2}{*}[T1]{$+[T 2]+[T 3]+[T 5]$ "All Information + Passport" } & $0.165^{*}$ & -0.029 & $0.177^{* *}$ & 0.092 & $0.165^{* *}$ & 0.112 & 0.047 & 0.064 \\
\hline & [0.090] & {$[0.042]$} & {$[0.080]$} & {$[0.062]$} & {$[0.081]$} & {$[0.072]$} & {$[0.056]$} & [0.054] \\
\hline \multirow[t]{2}{*}[\mathrm{T}1]{$+[\mathrm{T} 2]+[\mathrm{T} 3]+[\mathrm{T} 4]+[\mathrm{T} 5]$ "Full Assistance" } & $0.243^{* * *}$ & $0.195 * * *$ & 0.050 & $0.053^{*}$ & $0.067^{*}$ & $0.080 * *$ & $0.072 * *$ & 0.016 \\
\hline & [0.058] & [0.049] & {$[0.036]$} & {$[0.030]$} & [0.039] & {$[0.036]$} & [0.034] & [0.017] \\
\hline Sample Size & 1,453 & 1,453 & 1,453 & 1,453 & 1,453 & 1,453 & 1,453 & 1,453 \\
\hline Control group dependent variable mean & $10.2 \%$ & $1.9 \%$ & $6.1 \%$ & $2.3 \%$ & $5.6 \%$ & $3.3 \%$ & $3.3 \%$ & $1.4 \%$ \\
\hline$P$-value, coefficients jointly zero & $0.000 * * *$ & $0.000 * * *$ & 0.472 & $0.024 * *$ & 0.578 & 0.395 & 0.874 & 0.678 \\
\hline
\end{tabular}

Sample includes baseline respondents (ages 20-45) with completed endline surveys who reported being "interested" or "strongly interested" in working abroad at baseline. Stratification-cell fixed effects and baseline covariates described in Table 2 are included. Huber-White standard errors reported in brackets. 